\title{
Visible Policing: Technology, Transparency, and Democratic Control
}

Hannah Bloch-Wehba

Texas A\&M University School of Law, hbw@law.tamu.edu

Follow this and additional works at: https://scholarship.law.tamu.edu/facscholar

Part of the Civil Rights and Discrimination Commons, Criminal Law Commons, Criminal Procedure Commons, Fourth Amendment Commons, Law and Society Commons, and the State and Local

Government Law Commons

\section{Recommended Citation}

Hannah Bloch-Wehba, Visible Policing: Technology, Transparency, and Democratic Control, 109 Calif. L. Rev. 917 (2021).

Available at: https://scholarship.law.tamu.edu/facscholar/1503

This Article is brought to you for free and open access by Texas A\&M Law Scholarship. It has been accepted for inclusion in Faculty Scholarship by an authorized administrator of Texas A\&M Law Scholarship. For more information, please contact aretteen@law.tamu.edu. 


\title{
Visible Policing: Technology, Transparency, and Democratic Control
}

\author{
Hannah Bloch-Wehba*
}

\begin{abstract}
Law enforcement has an opacity problem. Police use sophisticated technologies to monitor individuals, surveil communities, and predict behaviors in increasingly intrusive ways. But legal institutions have struggled to understand-let alone set limits on-new investigative methods and techniques for two major reasons. First, new surveillance technology tends to operate in opaque and unaccountable ways, augmenting police power while remaining free of meaningful oversight. Second, shifts in Fourth Amendment doctrine have expanded law enforcement's ability to engage in surveillance relatively free of scrutiny by courts or by the public. The result is that modern policing is not highly visible to oversight institutions or the public and is becoming even less so.
\end{abstract}

DOI: https://doi.org/10.15779/Z38NS0KZ51

Copyright (C) 2021 Hannah Bloch-Wehba.

* Associate Professor, Texas A\&M University School of Law; Affiliated Fellow, Yale Law School Information Society Project; Affiliated Scholar, NYU School of Law Policing Project. For helpful comments and insights, I am grateful to Amna Akbar, Cynthia Alkon, Amy Cohen, Guillermo Garcia Sanchez, Paul Gowder, David Gray, Bruce Green, Orin Kerr, Christina Koningisor, Vida Johnson, Mark Kelman, Margaret Kwoka, Tim Mulvaney, Christopher Reed, David Sklansky, Christopher Slobogin, Norm Spaulding, and Nancy Welsh. My thanks as well to participants at the 2018 Privacy Law Scholars Conference, the 2019 Southeastern Association of Law Schools Conference, the 2019 CrimFest Annual Conference, the Governance Workshop at the University of Denver Sturm College of Law, the faculty workshops at Drexel, Cardozo, and Texas A\&M, the 2020 Stanford/Yale/Harvard Junior Faculty Forum, and the Dispute Resolution Works-in-Progress Consortium. Dean Dan Filler and Drexel University Thomas R. Kline School of Law provided generous research support for this project. Allie Daly and Jake Williams provided excellent and essential research assistance. David Haendler provided generous and much-needed library support. Finally, I am indebted to the terrific and patient editors of the California Law Review, including Ariana Abedifard, Aaron J. Cheung, Bella Coelho, Katharine Currault, Susana Herrera, Benjamin Malings, Cristina Mendez, Rudi Miller, Marcos Mocine-McQueen, Rodolfo E. Rivera Aquino, Rana Sahar, Aysha Spencer, Tyler Takemoto, Jenna Waldman, and Annabelle Wilmott, whose labor greatly improved my work. All errors are my own. 
In light of these informational dynamics, transparency litigation has become a core technique for rendering obscure investigative practices visible and holding police accountable. These new lawsuits form a criminal procedure "shadow docket"-they resolve important questions about democratic governance of policing without deciding on the constitutionality of searches and seizures. This Article builds on the government secrecy literature to explore the significance of this "shadow docket" and the relationship between transparency obligations and constitutional limits on police action. In the absence of meaningful Fourth Amendment safeguards, transparency litigation makes policing practices increasingly visible to the public and democratic institutions in areas where constitutional criminal procedure today has minimal reach. These efforts to make policing visible bear important lessons for advocates and scholars of criminal procedure, criminal justice reform, and transparency itself.

Introduction 919

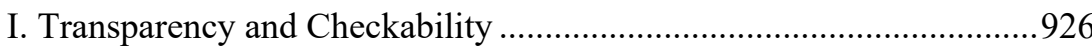

A. Information as Political Check.............................................926

B. Law Enforcement Transparency ……………......................929

II. Policy Visibility in Context.............................................................930

A. Three Policing Scenarios …………........................................

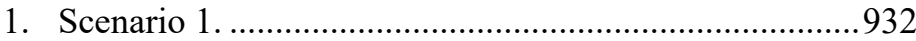

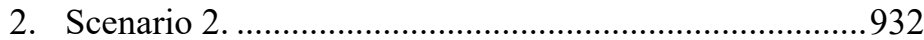

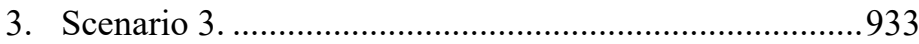

B. A Taxonomy of Law Enforcement Visibility ......................933

1. Visibility of What? .........................................................9934

2. Visibility to Whom? ……...............................................936

3. Visibility at What Time? ................................................938

C. The Challenge of Programmatic Policing............................939

III. Criminal Procedure's Shadow Docket...............................................943

A. Transparency Advocacy Challenging

Programmatic Policing

1. Stop, Question, Frisk ……………………....................944

2. Other "Broken Windows" programs..............................947

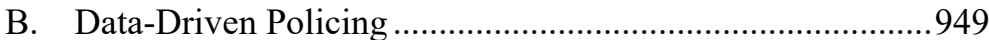

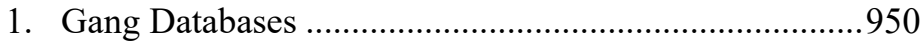

2. Private Sector Partnerships ............................................954

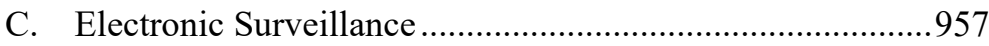

IV. Policing, Secrecy, and Democracy ...................................................961

A. Broadening the Range of Potential Litigants ........................961

B. Visibility, Trust, and Legitimacy ........................................965

C. The Transparency Two-Step................................................969

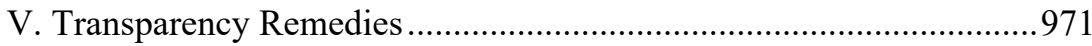


A. Transparency Outside the Shadow Docket .........................972

B. Procurement Reform...........................................................99

C. Community Control ..............................................................974

D. New Expert Oversight Institutions.......................................976

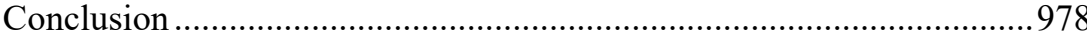

\section{INTRODUCTION}

Law enforcement has an opacity problem. ${ }^{1}$ Police use sophisticated technologies to monitor individuals, surveil communities, and predict behaviors in increasingly intrusive ways. But legal institutions have struggled to understand - let alone set limits on - new investigative methods and techniques for two major reasons. First, new surveillance technology tends to operate in opaque and unaccountable ways, augmenting police power while remaining free of meaningful oversight. Second, shifts in Fourth Amendment doctrine have expanded law enforcement's ability to engage in surveillance without oversight or scrutiny by courts or the public.

Consider police use of Automated License Plate Reader (ALPR) technology. ALPRs are cameras, often mounted at intersections or in police patrol cars, that photograph the license plates of passing vehicles and automatically screen them against a "hot list" of vehicles linked to crime. ${ }^{2}$ Using ALPRs, police can track a vehicle's movements throughout a city over timecreating a pervasive account of a car's location. Critics have grown concerned that ALPRs appear to be used disproportionately in low-income and non-White communities. ${ }^{3}$ In one stunning example of an ALPR contributing to police error,

1. See, e.g., Andrew Guthrie Ferguson, Illuminating Black Data Policing, 15 OHIO ST. J. CRIM. L. 503, 504 (2018); Stephanos Bibas, Transparency and Participation in Criminal Procedure, 81 N.Y.U. L. REV. 911, 911 (2006); Erik Luna, Transparent Policing, 85 IOWA L. REV. 1107, 1108-14 (2000); Barry Friedman \& Maria Ponomarenko, Democratic Policing, 90 N.Y.U. L. REV. 1827, 184850 (2015); Marc L. Miller \& Ronald F. Wright, The Black Box, 94 IowA L. REV. 125, 187-96 (2008); Barry Friedman, Secret Policing, 2016 U. CHI. Legal F. 99, 100-05; Heidi Kitrosser, "MacroTransparency" as Structural Directive: A Look at the NSA Surveillance Controversy, 91 MINN. L. REV. 1163, 1199-1200 (2007) (examining programmatic national security secrecy); Catherine Crump, Surveillance Policy Making by Procurement, 91 WASH. L. REV. 1595, 1606, 1629, 1640 (2016); Anil Kalhan, Immigration Surveillance, 74 MD. L. REV. 1, 69 (2014).

2. Tanvi Misra, Who's Tracking Your License Plate?, BloOMBERG CiTYLAB (Dec. 6, 2018), https://www.citylab.com/equity/2018/12/automated-license-plate-readers-privacy-data-securitypolice/576904/ [https://perma.cc/B3J3-3JPG].

3. Dave Maass \& Jeremy Gillula, What You Can Learn from Oakland's Raw ALPR Data, ELEC. FrONTIER FOUND. (Jan. 21, 2015), https://www.eff.org/deeplinks/2015/01/what-we-learnedoakland-raw-alpr-data [https://perma.cc/67DK-YXJ6]; see also Ángel Díaz \& Rachel LevinsonWaldman, Automatic License Plate Readers: Legal Status and Policy Recommendations for Law Enforcement Use, BRENNAN CTR. FOR JUST. (Sept. 10, 2020), https://www.brennancenter.org/ourwork/research-reports/automatic-license-plate-readers-legal-status-and-policy-recommendations [https://perma.cc/7WQ4-GDUJ] ("The NYPD has used license plate readers as part of its widespread surveillance of Muslim communities in the New York and New Jersey area."). 
police detained a Black family and forced them to lie on the ground after an ALPR flagged their minivan's license plate as a match to a stolen motorcycle. ${ }^{4}$

While it might be public knowledge that ALPRs exist, their particulars are often invisible to the public or oversight institutions. Civil society organizations and individuals concerned about the privacy and racial justice ramifications of ALPRs have turned to transparency law to uncover these practices. In 2015, the news outlet Ars Technica obtained 4.6 million ALPR records from the Oakland Police Department after filing a California open records request and then published a story about the privacy implications of license plate tracking. ${ }^{5}$ In Coral Gables, Florida, Raul Mas Canosa filed an open records request with the city seeking all the records it had on his car and then sued the city for violating his privacy rights. ${ }^{6}$

The Constitution regulates policing primarily through the Fourth Amendment's warrant requirement and prohibition of "unreasonable searches and seizures." ${ }^{7}$ But courts have consistently held that the use of ALPRs is not a "search" and that defendants may not exclude evidence obtained through a license plate reader. ${ }^{8}$ Although police use of ALPRs is common knowledgescholars and press outlets have discussed the systems at length-drivers may never learn that their particular location has been tracked, unless they are ultimately charged with a crime and ALPR evidence is brought against them. ${ }^{9}$

Modern policing depends on an array of techniques and technologies, like ALPRs, that are not considered "searches and seizures" and therefore lie outside

4. Teo Armus, Colorado Police Apologize over Viral Video of Officers Handcuffing Black Girls in a Mistaken Stop, WASH. POST (Aug. 4, 2020), https://www.washingtonpost.com/nation/2020/08/04/aurora-pd-handcuffs-family-gunpoint/ [https://perma.cc/YX59-BQST].

5. Cyrus Farivar, We Know Where You've Been: Ars Acquires 4.6M License Plate Scans from the Cops, ARS TECHNICA (Mar. 24, 2015), https://arstechnica.com/tech-policy/2015/03/we-knowwhere-youve-been-ars-acquires-4-6m-license-plate-scans-from-the-cops/ [https://perma.cc/6X5PCX34]. A similar set of records separately obtained from Oakland police demonstrated that the ALPRs were disproportionately used in low-income neighborhoods. See Maass \& Gillula, supra note 3.

6. Emma Cueto, 'Why Is My City Monitoring Me?,' LAw360 (Dec. 1, 2019), https://www.law360.com/articles/1223225/ [https://perma.cc/5RNX-5U3H].

7. U.S. CONST. amend. IV.

8. See, e.g., United States v. Diaz-Castaneda, 494 F.3d 1146, 1150 (9th Cir. 2007) (collecting cases).

9. For general discussion of ALPRs, see Misra, supra note 2; Julia M. Brooks, Drawing the Lines: Regulation of Automatic License Plate Readers in Virginia, 25 RICH. J.L. \& TECH. 1 (2019); Lauren Fash, Automated License Plate Readers: The Difficult Balance of Solving Crime and Protecting Individual Privacy, 78 MD. L. REV. OnLINE 63 (2019); Stephanie Foster, Should the Use of Automated License Plate Readers Constitute a Search After Carpenter v. United States?, 97 WASH. U. L. REV. 221 (2019); see also Amanda Levendowski, Trademarks as Surveillance Transparency, 36 BERKELEY TECH. L.J. (forthcoming 2021) (manuscript at 15-20), https://papers.ssrn.com/sol3/papers.cfm?abstract_id=3544195 [https://perma.cc/8R2X-ZW8F] (describing how federal trademark register discloses information about Vigilant Solutions' ALPR systems). 
of the Fourth Amendment's protections. ${ }^{10}$ These practices are not subject to longstanding Fourth Amendment safeguards, including ex ante judicial review and the exclusionary rule. ${ }^{11}$ Even surveillance techniques that might be considered "searches and seizures" often occur as part of "programmatic" and "suspicionless" police methodologies that are warrantless, data-driven, and not designed to generate convictions. ${ }^{12}$ Standing doctrine also shields many of these programs from legal challenges. ${ }^{13}$

ALPRs also exemplify the significant consequences of police surveillance not just for individual rights, but also for public and democratic oversight. Sophisticated policing technologies such as large DNA databases, social media monitoring, and facial recognition are often implemented without robust oversight or public awareness. ${ }^{14}$ The result is that law enforcement techniques that rely on advanced technologies are often less visible to individual targets, the judicial branch, and the public than their physical counterparts. ${ }^{15}$ This relative secrecy impedes efforts to rein in law enforcement activities through legislative

10. See, e.g., Jeramie D. Scott, Social Media and Government Surveillance: The Case for Better Privacy Protections for Our Newest Public Space, 12 J. BuS. \& TECH. L. 151, 158-59 (2017) (describing how Fourth Amendment doctrine does not protect social media posts "knowingly expose[d]" to the public eye); Christopher L. Izant, Equal Access to Public Communications Data for Social Media Surveillance Software, 31 HARV. J.L. \& TECH. 237, 242 (2017) ("There is no Fourth Amendment 'search' when the government views what a person makes public.").

11. The exclusionary rule is the requirement that "all evidence obtained by searches and seizures in violation of the Constitution" is inadmissible in court. Mapp v. Ohio, 367 U.S. 643, 654-55 (1961).

12. See infra Part III.A.

13. See David Gray, Collective Standing Under the Fourth Amendment, 55 AM. CRIM. L. REV. 77, 89 (2018) (describing how stringent Fourth Amendment standing rules "have put many search and seizure methods; means; and programs beyond the reach of effective Fourth Amendment regulation").

14. See, e.g., Kade Crockford, The FBI Is Tracking Our Faces in Secret. We're Suing., ACLU (Oct. 31, 2019), https://www.aclu.org/news/privacy-technology/the-fbi-is-tracking-our-faces-in-secretwere-suing/ [https://perma.cc/S5CH-HWW3]; Caroline Haskins, Amazon Requires Police to Shill Surveillance Cameras in Secret Agreement, VICE (July 25, 2019), https://www.vice.com/en us/article/mb88za/amazon-requires-police-to-shill-surveillance-cameras-insecret-agreement [https://perma.cc/5QHX-H8BE]; Kashmir Hill, The Secretive Company That Might End Privacy as We Know It, N.Y. TIMES (Jan. 18, 2020), https://www.nytimes.com/2020/01/18/technology/clearview-privacy-facial-recognition.html [https://perma.cc/BJV8-JF4K].

15. This dynamic is partly attributable to the unique set of rules that constrains transparency of digital searches. See, e.g., Hannah Bloch-Wehba, Exposing Secret Searches: A First Amendment Right of Access to Electronic Surveillance Orders, 93 WASH. L. REV. 145, 153 (2018) ("Routine sealing of court records ... implicates the public's right of access to judicial records and proceedings.”); Stephen Wm. Smith, Gagged, Sealed \& Delivered: Reforming ECPA's Secret Docket, 6 HARV. L. \& POL'Y REV. 313, 322-26 (2012) (discussing existing statutory provisions in Electronic Communications Privacy Act that foster electronic surveillance secrecy). It is also partly due to the political economy of surveillance technology. As Julie Cohen notes, "As digital technologies and capabilities furnished to the government by private contractors have become more central to national security and law enforcement operations, both the privileged status of trade secrets and the legal justifications asserted for protecting secrecy have changed." Julie E. Cohen, Between Truth And Power: The Legal Constructions of INFORMATIONAL CAPITALISM 133 (2019). 
or administrative oversight, litigation, and policymaking. ${ }^{16}$ In other words, doctrinal and technological developments yield distinctive informational dynamics: even as law enforcement expands the amount and types of information they collect about communities and individuals, the public and other stakeholders have remained comparatively in the dark about these practices. In light of these changes, transparency litigation has taken on a newly significant role in revealing investigative practices, stimulating public debate, and fostering meaningful democratic oversight.

Today, both formally and informally, many disputes about policing are about transparency. Transparency litigation, by which I mean litigation to compel the disclosure of government records, has become a core technique for rendering obscure investigative practices visible and holding police accountable. ${ }^{17}$ These lawsuits form a sort of criminal procedure "shadow docket." Although transparency litigation does not determine the merits of any law enforcement practice, program, or technology, these cases are nonetheless of central importance to criminal procedure and policing because they shape the conditions for institutional oversight, policy changes, and public resistance. Therefore, transparency litigation helps to resolve important questions about the democratic governance of policing without deciding on the constitutionality of searches and seizures. ${ }^{18}$

Accordingly, transparency litigation is not the primary mechanism through which the courts directly constrain criminal procedure or policing. Nonetheless, as this Article demonstrates, this docket meaningfully influences the protection of Fourth Amendment rights and values by rendering policing increasingly

16. Although the dominant strain of criminal procedure scholarship was long focused on the scope of constitutional rights, modern approaches are shifting to consider how other institutions might promote these and other values outside of the courts and outside of the "conventional paradigm" of constitutional law. See Rachel A. Harmon, The Problem of Policing, 110 MicH. L. REV. 761, 781 (2012) ("[L] egal scholars considering the problem of policing ... overwhelmingly take constitutional law to be their method ...."); see also Akhil Reed Amar, The Future of Constitutional Criminal Procedure, 33 AM. CRIM. L. REV. 1123, 1128-29 (1996) ("Not all sensible rules of criminal procedure can or should be constitutionalized.").

17. This litigation often takes the form of statutory open records or First Amendment lawsuits brought by journalists, news organizations, civil society organizations, or movement activists. See infra Part III; see also Jonathan Manes, Secrecy \& Evasion in Police Surveillance Technology, 34 BERKELEY TECH. L.J. 503, 512 (2019) ("Until there is a critical mass of public disclosure and public awareness, courts and legislatures generally do not publicly weigh in on the constitutional or statutory limits on the police's use of the novel technology.").

18. Other commentators have used the term "shadow docket" to denote the Supreme Court's non-merits orders and summary decisions, which do not resolve the merits of disputes but nonetheless have significant and enduring legal implications. William Baude, Foreword: The Supreme Court's Shadow Docket, 9 N.Y.U. J.L. \& LiBERTY 1, 4-5 (2015) (describing the Supreme Court's non-merits rulings as a "shadow docket" worthy of study); Stephen I. Vladeck, The Solicitor General and the Shadow Docket, 133 HARV. L. REV. 123 (2019); Steve Vladeck, Symposium: The Solicitor General, the Shadow Docket and the Kennedy Effect, SCOTUSBLOG (Oct. 22, 2020), https://www.scotusblog.com/2020/10/symposium-the-solicitor-general-the-shadow-docket-and-thekennedy-effect/ [https://perma.cc/49KS-6KQX] (suggesting that the "shadow docket" "record[s] everything other than the justices' formal rulings in argued cases"). 
visible to the public and democratic institutions. Indeed, transparency law is often now a critical advocacy tool for those seeking to hold law enforcement accountable and a critical component of efforts to shift public opinion, complementing the work of courts and oversight institutions. These efforts to stop intrusive policing practices are vital complements to traditional Fourth Amendment remedies and the relief available under civil rights law.

This Article's focus on democratic accountability brings together two distinct literatures considering the promise - and pitfalls - of broadening general public participation in and access to government. First, this Article links the secrecy and opacity of surveillance methods and practices to the burgeoning scholarly literature that proposes ways of making police more accountable and more democratic - including by abolishing, defunding, or stripping police of their power and resources. ${ }^{19}$ Amidst a nationwide uprising against police violence and oppression in 2020, movements and advocates have called for dramatic changes to policing. Some transparency-oriented reforms have already taken place, and others are underway. ${ }^{20}$

Second, policing also provides a new context for considering how the visibility of controversial government practices impacts democratic selfgovernance. In particular, the critical role of law enforcement transparency litigation is a modest counterargument to progressive critics of "open government" concerned that "transparency" is a thinly-veiled effort to weaken programs and agencies designed to promote the public welfare, promoting "reactionary" and regressive politics. ${ }^{21}$ But shining an unflinching light on the perils and failures of twenty-first century policing is consistent with the movements' political inclinations to dismantle or substantially reduce law

19. See infra Part I.B.

20. See Eric Umansky, We're Publishing Thousands of Police Discipline Records That New York Kept Secret for Decades, ProPuBLICA (July 26, 2020), https://www.propublica.org/article/nypdcivilian-complaint-review-board-editors-note [https://perma.cc/EKN9-QZFN]; Saja Hindi, Colorado Among First in U.S. to Pass Historic Police Reforms Following Protests, DENVER POST (June 13, 2020), https://www.denverpost.com/2020/06/13/colorado-police-reform-bill-passes-legislature/

[https://perma.cc/KY7R-MEDH]; Angel Idowu, \#ReleaseTheRecords Movement Seeks Release of Police Misconduct Files, WTTW NEWS (July 23, 2020), https://news.wttw.com/2020/07/23/releasetherecords-movement-seeks-release-police-misconduct-files [https://perma.cc/ETZ3-UD67]; Kyle Wiggers, NYC Passes POST Act, Requiring Police Department to Reveal Surveillance Technologies, VENTUREBEAT (June 18, 2020), https://venturebeat.com/2020/06/18/new-york-city-council-passes-law-requiring-nypd-to-reveal-itssurveillance-technologies/ [https://perma.cc/38FW-YABC].

21. David E. Pozen, Freedom of Information Beyond the Freedom of Information Act, $165 \mathrm{U}$. PA. L. REV. 1097, 1102 (2017) [hereinafter Freedom of Information]; David E. Pozen, Transparency's Ideological Drift, 128 YALE L.J. 100, 151 (2018) [hereinafter Ideological Drift] (arguing that the Freedom of Information Act aggravates a "mounting adversarialism" between government and public); Mark Fenster, The Opacity of Transparency, 91 IOWA L. REV. 885, 932 (2006) (expressing skepticism that open government laws can address "populist fears of secrecy, especially those that are deep-seated and lead to an all-encompassing distrust of the political order"). 
enforcement power. ${ }^{22}$ Examining the uses of transparency law and litigation in the context of law enforcement highlights the systemic importance of information —or the lack thereof - on efforts to change, curb, or altogether cease policing practices. And it underscores the integral role of contestation, resistance to authority, and "agonistic participation" in government institutions while acknowledging the potentially serious costs of those forms of participation to legitimacy. ${ }^{23}$

As the nation continues to reckon with police violence toward Black individuals and communities, changes to police surveillance and investigative tactics are overdue. As Devon Carbado has written, the law of police investigations shapes law enforcement's interactions with the public and can lead to brutality, oppression, and violence. ${ }^{24}$ The deaths of George Floyd, Breonna Taylor, Atatiana Jefferson, Eric Garner, Philando Castile, Alton Sterling, Michael Brown, Terence Crutcher, Keith Lamont Scott, Deborah Danner, Walter Scott, Laquan McDonald, Akai Gurley, John Crawford III, and countless others killed by police show that lives are very much at stake. Quantification, datadriven tools, and predictive techniques are reshaping policing, but killings, brutality, and misconduct remain. ${ }^{25}$ Substantial informational asymmetries confront organizers, advocates, and legal institutions who seek to change policing: police agencies often fight to conceal their technologies from the public and oversight institutions. ${ }^{26}$

But new police technology also creates new opportunities for transparency. Police technology entails reams of data and large numbers of government records: vendor proposals, contracts, training manuals, frequently asked questions, and many more artifacts. When it comes to transparency, police technology has two faces: it can conceal and expose information vital to both accountability and oversight. ${ }^{27}$ The result is that, while policing may be more secretive than in past eras, changes in policing practice may also have made transparency litigation a more feasible accountability strategy.

22. Amna A. Akbar, Toward a Radical Imagination of Law, 93 N.Y.U. L. REV. 405, 408 (2018) (emphasizing the Movement for Black Lives' focus on "shrinking the space of governance now reserved for policing, surveillance, and mass incarceration”).

23. Jocelyn Simonson, Democratizing Criminal Justice Through Contestation and Resistance, 111 Nw. U. L. REV. 1609, 1613 (2017).

24. Devon W. Carbado, From Stopping Black People to Killing Black People: The Fourth Amendment Pathways to Police Violence, 105 CALIF. L. REV. 125, 131 (2017) ("Fourth Amendment doctrine expressly authorizes or facilitates the very social practice it ought to prevent: racial profiling. This authorization and facilitation exposes African Americans not only to the violence of frequent police contact but also to the violence of police killings and physical abuse.").

25. See Aaron Shapiro, Predictive Policing for Reform? Indeterminacy and Intervention in Big Data Policing, 17 SURVEILLANCE \& SOC'Y 456, 460-61 (2019) (describing how police agencies view predictive policing as a reformist tool).

26. See also Manes, supra note 17.

27. See Andrew Guthrie Ferguson, The Exclusionary Rule in the Age of Blue Data, 72 VAND. L. REV. 561, 567-68 (2019) ("New data surveillance systems built by the police can also be used to monitor systemic and recurring police practices."). 
This Article makes three contributions. First, it demonstrates how doctrinal and technological changes have exacerbated obstacles to transparency and have made it increasingly difficult to check policing. ${ }^{28}$ Second, this Article observes that the informational dynamics of modern policing affect the efficacy of oversight institutions and community control mechanisms alike. While transparency law is increasingly fueling advocacy efforts by movement groups and grassroots organizations, it has also become a critical tool for formal institutions engaged in monitoring and oversight.

Finally, this Article considers the lessons these informational dynamics bring to efforts to reform police governance. Transparency values lie at the core of procedural justice and democratic policing, two approaches intended to repair the "legitimacy" of criminal law enforcement institutions. Transparency is equally essential to the progressive and abolitionist project of recentering affected communities in control and oversight of policing. By relying on open government tools, reformers seek to shed light on criminal law enforcement institutions in the interests of promoting community control and accountability. ${ }^{29}$ Examining these efforts provides a modest rejoinder to those who are skeptical about the value of transparency and "open government" to democratic governance and public trust. ${ }^{30}$

This Article proceeds in five parts. Part I begins by briefly reviewing how scholars have invoked openness values in constitutional law and criminal procedure. Part II highlights how Fourth Amendment doctrine can promote information-forcing and sets forth how the shift from an individualist, warrantbased model of policing toward a programmatic, reasonableness-based model

28. Policing is not the only context in which advocates have looked to transparency law in the absence of standing. Similar moves are visible in settings as disparate as voting rights, reproductive rights, immigration, and national security. This Article saves for another day, however, a fuller analysis of the ways in which onerous standing and pleading requirements, barriers to discovery, and other impediments to relief have led advocates to turn to transparency law as the initial part of a "two-step litigation" strategy.

29. See, e.g., Dan Sloan, A World Without Prisons: A Conversation with Mariame Kaba, LUMPEN MAGAZINE (Apr. 7, 2016) http://web.archive.org/web/20190503093113/http://www.lumpenmagazine.org/a-world-withoutprisons-a-conversation-with-mariame-kaba/ ("Transparency does help very much to give the community tools and information that they need to advocate for themselves and their kids around these issues."); Stops, Transparency, Oversight and Protection Act (STOP Act), We CHARGE GENOCIDE, http://wechargegenocide.org/stop.act/ [https://perma.cc/A2S9-FWRZ] (calling for the passage of the Stops, Transparency, Oversight and Protection Act (STOP Act) to require Chicago police to share data on stops); Right to Know Act, CMTYS. UNITED FOR POLICE REFORM, https://www.changethenypd.org/RightToKnowAct [https://perma.cc/FTF4-QRTA] (calling for the passage of the Right to Know Act to require NYPD to identify themselves and articulate a reason for a stop or other civilian encounter).

30. See, e.g., Pozen, Ideological Drift, supra note 21, at 151 (illustrating that declining trust in institutions may be related to demands for more transparency); Fenster, supra note 21, at 949 ("Transparency advocates' failure to recognize the impossibility of achieving perfect democratic governance and a thoroughly informed and engaged public results in a frustrating and often ineffective legal regime.”). 
has strained law enforcement transparency. Part III documents how, in response to the erosion of procedural and substantive Fourth Amendment protections, current efforts to reform policing draw on both the formal mechanisms of transparency litigation and the animating values of transparency lawdemocratic self-governance, participation, and accountability. Part IV considers the normative benefits and potential drawbacks of relying on transparency's "shadow docket" to advance the law of policing. Part V explores lessons for reform efforts to improve law enforcement transparency and oversight.

I.

\section{TRANSPARENCY AND CHECKABILITY}

To contextualize the informational dynamics that afflict policing, this Section begins by surveying how constitutional theorists have justified openness and transparency as essential qualities of democratic governance. Despite the controversial nature of open government mandates, advocates for criminal law enforcement reform have embraced principles of transparency and open government as central to the project of democratizing police.

\section{A. Information as Political Check}

The assumption that openness in government is critical to democracy runs deep throughout democratic theory and constitutional law. ${ }^{31}$ At least in theory, the flow of information from the government to the public is a key aspect of popular sovereignty. ${ }^{32}$ But informational flow within government might be equally significant. As Heidi Kitrosser has described it, one might envision secrecy as existing along a "spectrum" that can signal whether a secret is more or less troubling to democratic norms. ${ }^{33}$ In David Pozen's terminology, a secret is "deep" if government actors work to "conceal[] its existence from the public and from other officials," frustrating both public oversight and checks and balances. ${ }^{34}$ On the other end of the spectrum, a secret is "shallow" if "ordinary citizens understand they are being denied relevant information and have some ability to estimate its content." 35 To understand the depth of a secret, one might

31. See, e.g., Fenster, supra note 21, at 898 (describing theoretical and political assumptions "that the publicity of open government produces an informed and interested public, and by implication, that secrecy caused by opaque or closed government produces suspicious and/or ignorant masses"); Andrew Guthrie Ferguson, Policing Predictive Policing, 94 WASH. U. L. REV. 1109, 1168 (2017) ("Improved transparency leads to increased accountability.").

32. Heidi Kitrosser, Secrecy and Separated Powers: Executive Privilege Revisited, 92 Iowa L. REV. 489, 515 (2007). But see, e.g., Barry P. McDonald, The First Amendment and the Free Flow of Information: Towards a Realistic Right to Gather Information in the Information Age, 65 OHIO ST. L.J. 249, 251-52 (2004) (describing the Court's "erratic and fragmented" approach to newsgathering).

33. Kitrosser, supra note 32, at 514.

34. David E. Pozen, Deep Secrecy, 62 StAN. L. ReV. 257, 274 (2010).

35. Id. 
consider whether the policy of secrecy is, itself, visible, politically accountable, and reversible. ${ }^{36}$

The "deep/shallow" distinction is important not just to the public but also to interbranch oversight. As Kitrosser has put it, a "shallow" secret is more likely to be conducive to "political[] checkability," because a legislature is more capable of exercising political control over secrets that it knows exists. ${ }^{37}$ Publicity about government policy choices might also promote legislative oversight indirectly by stimulating constituent concerns ${ }^{38}$ or prompting investigative reporting ${ }^{39}$ that leads to legislative oversight. ${ }^{40}$ "Shallowness" does not, standing alone, ensure that legislative controls will prove effective, but it is a necessary precondition for oversight. ${ }^{41}$ Accordingly, determining what kinds of information ought to be disclosed, to whom, and when, has constitutional implications. ${ }^{42}$

What Kitrosser calls "openness legislation"-statutory interventions that promote informational flow either among the branches or between the

36. Kitrosser, supra note 32 , at 515.

37. Id. Kitrosser thus concluded that the executive branch should be permitted to operate in secret, subject to any statutory limitations enacted by Congress. Id. at 528 .

38. See, e.g., Alexandra Yoon-Hendricks, Giving Others a Voice in Congress, One HandDelivered Letter at a Time, N.Y. TIMES (Aug. 17, 2018), https://www.nytimes.com/2018/08/17/us/politics/herd-on-the-hill-constituent-outreach.html [https://perma.cc/AJJ3-7QB9] (explaining that an organization of 300 volunteers "deliver[ed] more than 12,000 letters to congressional offices on behalf of constituents seeking to inject a human element into the issues roiling the country").

39. See, e.g., Eric Lipton \& Jesse Drucker, Lawmakers Increase Criticism of 'Opportunity Zone' Tax Break, N.Y. Times (Nov. 6, 2019), https://www.nytimes.com/2019/11/06/business/opportunityzones-congress-criticism.html [https://perma.cc/DG9L-G3YA] (“Congressional Democrats are calling for investigations and legislative fixes in the wake of reporting by The [New York] Times.").

40. According to this theory, a lack of information is partly to blame for historically anemic congressional oversight of controversial executive branch national security programs, such as programmatic communications surveillance, rendition and detention, and blacklisting of travelers. See Heidi Kitrosser, Congressional Oversight of National Security Activities: Improving Information Funnels, 29 CARDOZO L. REV. 1049, 1053 (2008) (discussing Bush Administration's notification of the "Gang of Eight" regarding warrantless wiretapping); Jenny-Brooke Condon, Illegal Secrets, 91 WASH. U. L. REV. 1099, 1115 (2014) (warrantless wiretapping); Robert M. Chesney, State Secrets and the Limits of National Security Litigation, 75 GEO. WASH. L. REV. 1249 (2007); Ian MacDougall, Note, CIPA Creep: The Classified Information Procedures Act and Its Drift into Civil National Security Litigation, 45 COLUM. HUM. RTS. L. REV. 668, 699 (2014) (discussing no-fly list litigation); Justin Florence, Note, Making the No Fly List Fly: A Due Process Model for Terrorist Watchlists, 115 YALE L.J. 2148 (2006)

41. See Amanda Frost, The State Secrets Privilege and Separation of Powers, 75 FORDHAM L. REV. 1931, 1951 (2007) (describing the state secrets privilege as an attempt to "narrow federal jurisdiction" and simultaneously deprive Congress and the courts of authority to regulate government secrecy).

42. See, e.g., Kitrosser, supra note 32; Dakota S. Rudesill, Coming to Terms with Secret Law, 7 Harv. NAT'L SeC. J. 241 (2015); Adam M. Samaha, Government Secrets, Constitutional Law, and Platforms for Judicial Intervention, 53 UCLA L. REV. 909 (2006); Jonathan Hafetz, A Problem of Standards?: Another Perspective on Secret Law, 57 WM. \& MARY L. REV. 2141 (2016); Jonathan Manes, Secret Law, 106 GEO. L.J. 803 (2018). 
government and the people - plays a critical role in promoting checkability. ${ }^{43}$ "Open government" statutes that require government entities to disclose records, such as the federal Freedom of Information Act (FOIA) and its state equivalents, are paradigmatic examples of openness legislation. ${ }^{44}$ These statutes generally create a presumption that government records should be disclosed to a member of the public upon request, exempt certain categories from disclosure, and create a private right of action that permits individuals to enforce these mandates. ${ }^{45}$

"Open government" statutes are polarizing. Critics of these statutory frameworks charge that "open government" principles do little to promote accountability for government practices but rather tend to empower moneyed interests, undercut the legitimacy of the state, and devalue personal privacy. ${ }^{46}$ As Mark Fenster argues, transparency advocates often rely upon a "deeply populist" vision of the state, one in which "a distant, secretive bureaucracy rules the nontransparent state" in ways that are estranged from the popular will. ${ }^{47}$ And the evidence that open government obligations across a broad array of areas have, in fact, improved governance is scant. ${ }^{48}$ Instead of fostering oversight by investigative journalists and civil society, open government laws have invited business lobbyists into the legislative and administrative state. They have permitted right-wing organizations to "reframe facts, obscure the overall shape of government activity, and sow alienation." 49 In their current form, critics contend, transparency obligations are not only unnecessary to advance a reformist agenda but are in fact sometimes counterproductive, serving neoliberal ends. ${ }^{50}$ These critics also doubt that "open government" and freedom of information can meaningfully check the most egregious forms of secrecy. ${ }^{51}$

43. Kitrosser, supra note 32, at 514 (explaining that openness obligations are "antagonistic" to deep secrecy and conducive to checkability).

44. Pozen, Ideological Drift, supra note 21, at 118 (describing FOIA as the "canonical" openness legislation).

45. Pozen, Freedom of Information, supra note 21, 1102-03.

46. See Pozen, Ideological Drift, supra note 21, at 123 ("In its actual application, however, transparency has become increasingly associated with institutional incapacity and with agendas that seek to maximize market freedom and shrink the state."); see also Mark Fenster, Seeing the State: Transparency as Metaphor, 62 ADMIN. L. REV. 617, 628 (2010) ("“T]ransparency ... offers a highly charged metaphor of a corrupt, secretive state that must be made visible."); Julie E. Cohen, The Inverse Relationship Between Secrecy and Privacy, 77 SOC. RSCH. 883, 890-91 (2010) (observing that ideals of "openness" underwrite corporate surveillance and monetization of personal information); Kate Levine, Discipline and Policing, 68 DUKE L.J. 839, 854 (2019) (recognizing many scholars "have argued that there are serious tradeoffs that come with overreliance on visibility").

47. Fenster, supra note 46, at 629.

48. See Pozen, Ideological Drift, supra note 21, at 127-32.

49. Id. at $149-50$.

50. Id. at $147-48$.

51. Id. at $155-56$ (" $[E]$ ven as the transparency laws of the 1960 s and 1970 s placed increasingly onerous demands on the domestic policy process, they grew increasingly detached from the state's most violent and least visible components."). 


\section{B. Law Enforcement Transparency}

Strikingly, though, advocates of reforming law enforcement and criminal justice institutions appear not to share these doubts. ${ }^{52}$ Calls for police transparency make headlines on a regular basis. ${ }^{53}$ Advocacy groups and reporters painstakingly reconstruct details of police-union contracts ${ }^{54}$ and use-of-force incidents. ${ }^{55}$ Civil society organizations demand statutory changes to promote transparency in police-civilian encounters, surveillance oversight, and bodycamera law. ${ }^{56}$ Scholars have embraced these calls, situating transparency as a central pillar in efforts to promote public trust in law enforcement, police accountability, and compliance with the law itself.

Contemporary theories about how to improve policing and reduce its footprint in American communities reflect growing and shared commitments to transparency as a potential remedy for law enforcement's precarious relationship with the public. ${ }^{57}$ Barry Friedman and Maria Ponomarenko, for instance, argue

52. Kate Levine is a notable exception and has argued that the focus on transparency and disclosure for police disciplinary records is misplaced. See Levine, supra note 46, at 846.

53. See, e.g., Jodi S. Cohen \& Jennifer Smith Richards, Police Oversight Ordinance Promised Transparency but Doesn't Fully Deliver, ProPublica (Nov. 13, 2017), https://www.propublica.org/article/copa-chicago-police-oversight\#: :text=Accountability

[https://perma.cc/VDR2-Y3T6]; Editorial, Charlotte's Mayor, City Council Need to Answer These Questions About Police Shooting Video, ChARLOTTE OBSERVER (Apr. 22, 2019), https://www.charlotteobserver.com/opinion/editorials/article229534219.html [https://perma.cc/MGR9EEUV]; Editorial, More Police Transparency Can Repair Public Distrust, NEWS-TIMES (May 18, 2019), https:/www.newstimes.com/opinion/article/Editorial-More-police-transparency-can-repair13854753.php [https://perma.cc/QTF9-CTVD]; Christian Morrow, Wolf Vetoes Bill That Would Bar Identifying Police, New PITTSBurgh COURIER, Nov. 23, 2016, at A1, A5, https://newpittsburghcourier.com/2016/11/23/wolf-vetoes-bill-that-would-bar-identifying-police/ [https://perma.cc/A8QR-5BZW]; Robert Mackey, Charlotte Police Chief Refuses to Release Dashcam Video of Officer Killing Keith Scott, INTERCEPT (Sept. 22, 2016), https://theintercept.com/2016/09/22/charlotte-police-chief-refuses-to-release-dashcam-video-ofofficer-killing-keith-scott/ [https://perma.cc/57TK-9CRP].

54. See, e.g., Police Union Contract Project, CHECK THE POLICE, https://www.checkthepolice.org/ [https://perma.cc/J47P-VNFJ].
55. See,
e.g.,
WASH.
POST:
FATAL FORCE
(2016),

https://www.washingtonpost.com/policeshootings [https://perma.cc/C5LQ-3K5H].

56. See Wiggers, supra note 20; Right to Know Act, supra note 29.

57. See infra Part IV.B. There is a large literature on police transparency, but it largely does not address the secrecy of investigative methods. Many scholars have called for additional transparency for police as people, noting the urgent need for more accountability for police misconduct. See, e.g., Cynthia $\mathrm{H}$. Conti-Cook, A New Balance: Weighing Harms of Hiding Police Misconduct Information from the Public, 22 CUNY L. ReV. 148 (2019); Cynthia H. Conti-Cook, Open Data Policing, 106 GeO. L.J. OnLine 1 (2017); Rachel Moran, In Police We Trust, 62 VILL. L. REV. 953 (2017); Rachel Moran, Ending the Internal Affairs Farce, 64 BUFF. L. REV. 837 (2016); see also Levine, supra note 46. Others have focused on the uniquely deferential treatment afforded to police agencies in comparison to other democratic institutions, noting that police seem to enjoy a string of exceptions to general obligations of transparency, accountability, and oversight. See, e.g., Friedman \& Ponomarenko, supra note 1; Daphna Renan, The Fourth Amendment as Administrative Governance, 68 STAN. L. REV. 1039 (2016); Erik Luna, Transparent Policing, 85 IowA L. REV. 1107 (2000); Anna Lvovsky, The Judicial Presumption of Police Expertise, 130 HARV. L. REV. 1995 (2017); see also Margaret B. Kwoka, Deferring to Secrecy, 
that "democratic policing" requires that the legal authorities which constrain other agencies also apply to police. ${ }^{58}$ Transparency obligations are no exception. Proponents of procedural justice see transparency in large part as an important instrument for attaining public trust. ${ }^{59}$ Still others have considered broader extensions of transparency, including within the grand jury, bail, trial, sentencing, and plea-bargaining systems, to permit a broader set of actors (beyond the parties, attorneys, and judges) to oversee or participate in criminal justice processes. ${ }^{60}$

But while a growing consensus supports more transparent policing as a matter of policy, it has largely failed to grapple with the ways in which new technologies and doctrinal shifts undermine those efforts by permitting-and sometimes encouraging-widespread investigative secrecy. ${ }^{61}$ These informational dynamics reflect a fundamental challenge to police reform and to the democratic legitimacy of policing decisions. Obtaining information about what the police are doing - the tools they are using, the practices they are engaged in, and the limits of their activities - is a fundamental predicate to ensuring that the promise of democratic control (whether by courts, legislatures, other formal oversight institutions, civil society, social movements, or individual defendants) is real.

II.

\section{POLICY VISIBILITY IN CONTEXT}

While today secrecy norms appear embedded in law enforcement culture and practice, for decades, law enforcement routinely disclosed fairly extensive information about how police investigated crime. Longstanding Fourth Amendment doctrine and practice embrace a variety of "information-forcing"

54 B.C. L. REV. 185, 216-17 (2013) (describing two different situations where law enforcement agencies enjoy "privileged legal status").

58. Friedman \& Ponomarenko, supra note 1, at 1848-49 (describing various types of police obfuscation and evasion of transparency).

59. Tracey L. Meares \& Tom R. Tyler, Justice Sotomayor and the Jurisprudence of Procedural Justice, 123 YALE L.J.F. 525, 535 (2014) ("Many judges devote their attention to being fair, i.e., to correctly applying the law to the facts of each case, but do not think about how they can communicate that they are being fair to the parties in the case or to the public more generally.").

60. See Jocelyn Simonson, The Criminal Court Audience in a Post-Trial World, 127 HARV. L. REV. 2173 (2014); Jocelyn Simonson, Copwatching, 104 CALIF. L. REV. 391 (2016); Jocelyn Simonson, Beyond Body Cameras: Defending a Robust Right to Record the Police, 104 GEO. L.J. 1559 (2016); Lauren M. Ouziel, Prosecution in Public, Prosecution in Private (unpublished manuscript) (on file with author); Jenia I. Turner, Transparency in Plea Bargaining, 96 NOTRE DAME L. REV. 973 (2021); Laura I. Appleman, Justice in the Shadowlands: Pretrial Detention, Punishment, \& the Sixth Amendment, 69 WASH. \& LEE L. REV. 1297 (2012); Laura I. Appleman, The Plea Jury, 85 IND. L.J. 731 (2010); Andrea Kupfer Schneider \& Cynthia Alkon, Bargaining in the Dark: The Need for Transparency and Data in Plea Bargaining, 22 NEW CRIM. L. REV. 434 (2019).

61. Cf. Rachel Harmon, Why Do We (Still) Lack Data on Policing?, 96 MARQ. L. REV. 1119 (2013) (considering efforts to prompt law enforcement to produce, collect, and share data about policing). 
mechanisms, most notably through the requirement to obtain a search warrant and give notice to the target of a search. ${ }^{62}$ The erosion of these requirements has had significant and well-documented effects on individual privacy and on nonWhite communities. ${ }^{63}$ The impact on transparency and democratic governance, however, has been relatively underappreciated. Diminished Fourth Amendment protections have also made it much more difficult for courts, defendants, and the public to get critical information necessary to check the police. The hypothetical scenarios that follow illustrate these shifts and demonstrate how parallel evolutions in legal doctrine and in law enforcement practice have created opportunities for law enforcement to act in secret, yielding substantial transparency gaps.

\section{A. Three Policing Scenarios}

The "canonical fact pattern[s]" of criminal procedure involve discrete, physical encounters between individuals and law enforcement. ${ }^{64}$ Likewise, the canonical Fourth Amendment cases primarily involve individual defendants seeking to suppress evidence that was gleaned from an allegedly unlawful search or seizure ${ }^{65}$ or individual plaintiffs seeking relief for an unconstitutional harm. ${ }^{66}$

62. "Information forcing" is often linked to contract theory. See, e.g., Ian Ayres \& Robert Gertner, Filling Gaps in Incomplete Contracts: An Economic Theory of Default Rules, 99 YALE L.J. 87, 99-100 (1989) (discussing how information asymmetries can lead to inefficient and suboptimal contracting outcomes); Yair Listokin, Learning Through Policy Variation, 118 YALE L.J. 480, 501-03 (2008) (discussing information-forcing contracting rules in the context of Hadley v. Baxendale). But discussions of information-forcing have found their way into other areas of the law as well, including criminal procedure. See, e.g., Mary D. Fan, The Police Gamesmanship Dilemma, 44 U.C. DAVIS L. REV. 1407, 1479 (2011) ("In the criminal procedure context law enforcement officers and agencies are sophisticated repeat players in the best position to collect, aggregate and report data and rationales."); see also Bradley C. Karkkainen, Information-Forcing Environmental Regulation, 33 FLA. ST. U. L. REV. 861 (2006) (environmental law); Alex Reinert, Pleading as Information-Forcing, 75 LAW \& CONTEMP. PROBS. 1 (2012) (pleading standards); Andrew D. Bradt \& D. Theodore Rave, The Information-Forcing Role of the Judge in Multidistrict Litigation, 105 CALIF. L. REV. 1259 (2017) (multidistrict litigation).

63. See, e.g., David A. Harris, Factors for Reasonable Suspicion: When Black and Poor Means Stopped and Frisked, 69 IND. L.J. 659, 659 (1994) ("[B]eing stopped for nothing —or almost nothinghas become an all-too-common experience for some Americans since 1968, when the United States Supreme Court decided Terry v. Ohio."); Tracey Maclin, Race and the Fourth Amendment, 51 VAND. L. REV. 333, 364-65 (1998) (noting that the Terry Court was "troubled" by the racial impact of stop and frisk, although it ultimately blessed the practice).

64. Orin S. Kerr, Searches and Seizures in a Digital World, 119 HARV. L. REV. 531, 536 (2005); see also Renan, supra note 57, at 1051 ("Modern Fourth Amendment jurisprudence developed around a transactional conception of the police-citizen encounter that, in turn, framed the legal tests governing search and seizure.").

65. Mapp v. Ohio, 367 U.S. 643 (1961).

66. See, e.g., Safford Unified Sch. Dist. No. 1 v. Redding, 557 U.S. 364, 364 (2009) (describing Section 1983 action against school district for strip search of thirteen-year-old girl); City of Ontario v. Quon, 560 U.S. 746, 746 (2010) (describing Section 1983 action against city and police department for reviewing text messages received on official pager); Brower v. Cnty. of Inyo, 489 U.S. 593, 594 (1989) (describing Section 1983 action against county police for roadblock that killed a suspect); see also Floyd 
Yet this doctrinal orientation toward individual rights sometimes overlooks more basic questions about what different actors involved with law enforcement investigations know about policing. The presumption of Fourth Amendment doctrine is that individuals know when their persons, houses, papers, or effects are searched, that courts have an opportunity to weigh in on the constitutionality of a search, and that the legislature can respond to intrusive police conduct by enacting laws that constrain police investigations. As these scenarios demonstrate, these presumptions are not always supported.

\section{Scenario 1 .}

An undercover police officer investigating you for participating in a fraud conspiracy visits your office under false pretenses while you are out. Telling the receptionist that they are a friend, they rifle through your papers and, unbeknownst to you, steal several documents. Six months later, the police apply for a warrant to search your office for "letters, papers, documents, and writings" relating to the conspiracy. ${ }^{67}$ When the undercover officer testifies before the grand jury, you find out about the secret theft of the documents.

The undercover officer's conduct was not only a search: for a time, it was also a secret. ${ }^{68}$ Because the officer did not apply for a warrant, law enforcement did not inform, much less seek the approval of, a "neutral and detached magistrate" before performing the search. ${ }^{69}$ Nor did the officer leave notice or an inventory behind them, which would have permitted you to know that the search took place and that documents were taken. But the search did not stay a secret for long: you eventually found out because the officer's testimony was critical to the criminal case against you.

\section{Scenario 2.}

An urban police department engages in a pattern of stopping, questioning, and frisking individuals based on reasonable suspicion that they are engaged in crime, are about to engage in crime, or are armed and dangerous. The stops occur in public, often with witnesses present. ${ }^{70}$ It is common knowledge that thousands of people are stopped and frisked each year and that only a small proportion of those stopped are ultimately arrested on any charge. When asked to release the aggregate data on the stop-and-frisk program, which would include demographic

v. City of New York, 959 F. Supp. 2d 540, 658 (S.D.N.Y. 2013) (describing Section 1983 action against New York for unlawful stop-and-frisk policy).

67. Gouled v. United States, 264 F. 839, 840 (2d Cir. 1920), certifying questions to 255 U.S. 209 (1921).

68. Gouled v. United States, 255 U.S. 209, 305 (1921).

69. Johnson v. United States, 333 U.S. 10, 13-14 (1948).

70. Nicholas K. Peart, Opinion, Why Is the N.Y.P.D. After Me?, N.Y. TiMES (Dec. 17, 2011), https://www.nytimes.com/2011/12/18/opinion/sunday/young-black-and-frisked-by-the-nypd.html [https://perma.cc/W2PD-MDGQ]. 
information about the individuals stopped, the reasons for stops, and the locations of stops, the police decline to do so. ${ }^{71}$

The stop-and-frisk program is not a secret. ${ }^{72}$ Individuals obviously know that they have been stopped, questioned, and frisked; those who have not had such encounters with the police often know somebody who has. Communities, civil society organizations, and social movements coalesce around protesting the practice. But while stop-and-frisk is no secret, it still is not transparent. The data that police refuse to produce would provide information critical to understanding how the program functions and how it might produce or rely upon racial bias. That data is essential for meaningful oversight by city councils, by courts asked to review the program's constitutionality, and by members of the press and public seeking to hold the police to account.

\section{Scenario 3.}

The Federal Bureau of Investigation (FBI) obtains a search warrant directed to an electronic communication service provider, seeking access to the contents of your email. The FBI also obtains a separate court order "commanding" the recipient not to notify any person of the existence of the order. ${ }^{73}$ As a result, the service provider turns over access to your emails but remains barred from informing you of the search. While the federal government publishes no data about how frequently it uses email search warrants or nondisclosure orders, communication service providers reportedly receive tens of thousands of search warrants each year. ${ }^{74}$

The searches are not a complete secret, but nor are they transparent. Because the search and the nondisclosure orders are issued by the court, they enjoy some supervision by a magistrate. ${ }^{75}$ However, the recipient of the warrant is gagged from speaking about it, and you are unaware that your emails have been searched. ${ }^{76}$ Unless you are charged with a crime and move to suppress the evidence, you may never find out that the search occurred at all. ${ }^{77}$ The result is that while the search is known to the judicial branch, it remains a secret to youthe individual affected - and to the public. ${ }^{78}$

\section{B. A Taxonomy of Law Enforcement Visibility}

While the primary function of the Fourth Amendment is to protect individual rights to privacy and security, its facilitation of public knowledge,

71. See infra Part III.A.1 (discussing NYPD's reluctance to release stop-and-frisk data).

72. See Wayne R. LaFave, "Street Encounters" and the Constitution: Terry, Sibron, Peters, and Beyond, 67 Mich. L. REV. 39, 43 (1968).

73. 18 U.S.C. $\S 2705$ (b).

74. Bloch-Wehba, supra note 15, at 161.

75. 18 U.S.C. $\$ 2705$.

76. See Microsoft Corp. v. U.S. Dep't of Just., 233 F. Supp. 3d 887, 895 (W.D. Wash. 2017).

77. 18 U.S.C. $\S 2705$.

78. Bloch-Wehba, supra note 15. 
oversight, and participation in governance are important secondary effects. ${ }^{79} \mathrm{In}$ this Section, I offer some potential ways of characterizing these considerationsfollowing Kitrosser - as a spectrum that considers how visible policing is to different actors and at different moments. ${ }^{80}$ Considering the flow of information about policing - transparency of what, to whom, and when - helps to explain the conditions that make democratic oversight of police more or less robust.

\section{Visibility of What?}

We might begin with the principle that the fact that a search has occurred is usually public. For example, an ordinary, physical search of a home-what Orin Kerr has called the "canonical fact pattern" of Fourth Amendment lawtakes place only pursuant to a warrant. ${ }^{81}$ By its nature, the warrant requires disclosure by the police to a magistrate: the police must describe the thing to be searched with particularity and establish probable cause for the search. ${ }^{82}$

The fact of a search is ordinarily made plain to the target as well. Continuing with the canonical case of a home search, the occupant may well be home to observe the search taking place. ${ }^{83}$ For instance, the rules governing physical searches of the home include the requirement that the police "knock and announce" before entering. ${ }^{84}$ Today, the "knock and announce" rule is often described as a pragmatic one: by announcing their purpose before entering a home, police avoid threats to their own safety and to those of the home's inhabitants. ${ }^{85}$ But "knock and announce" is rooted in the requirement of notice to the target of a search. ${ }^{86}$

The principle of notice also protects a person's right to know that they have been searched after the fact. In the seminal case of Wilkes $v$. Wood, ${ }^{87}$ a dissenting 2184.

79. See, e.g., Simonson, The Criminal Court Audience in a Post-Trial World, supra note 60, at

80. Kitrosser, supra note 32.

81. Kerr, supra note 64; see also Stephanie M. Stern, The Inviolate Home: Housing Exceptionalism in the Fourth Amendment, 95 CORNELL L. REV. 905, 912-18 (2010) (exploring the typical search of the physical home in Fourth Amendment jurisprudence).

82. U.S. CONST. amend. IV.

83. See, e.g., Schitt's Creek: Our Cup Runneth Over (Feb. 11, 2015) (depicting the Rose family observing as the revenue agency seizes all their assets in the first scene of the series).

84. Wilson v. Arkansas, 514 U.S. 927, 930 (1995).

85. 3 Wayne LaFave, Search \& Seizure: A Treatise on the Fourth AMENDMENT $\S$ 6.2(a) (6th ed. 2020), Westlaw (database updated Sept. 2020) (“(1) [I]t reduces the potential for violence to both the police officers and the occupants of the house into which entry is sought; (2) it guards against the needless destruction of private property; and (3) it symbolizes the respect for individual privacy summarized in the adage that "a man's house is his castle." (quoting United States v. Bustamante-Gamez, 488 F.2d 4 (9th Cir.1973))).

86. See Miller v. United States, 357 U.S. 301, 309 (1958) (finding that the Fourth Amendment "seems to require notice in the form of an express announcement by the officers of their purpose for demanding admission"); Ker v. California, 374 U.S. 23, 49 (1963) (Brennan, J., concurring in part) (noting the requirement that officers announce their "purpose and authority" before entering a home is "of the essence of the substantive protections which safeguard individual liberty").

87. (1763) 98 Eng. Rep. 489; Lofft, 1. 
printer filed an action for trespass after the government searched and seized all of their papers; a chief objection to the blanket search was that the searchers had failed to leave an inventory behind. ${ }^{88}$ At a minimum, the logic ran, the government had to inform the target of what had been taken.

The warrant requirement mitigates secrecy in a second way, by requiring the police to obtain judicial approval prior to a search, facilitating interbranch oversight. The search warrant requirement thereby drastically lowers the secrecy with which law enforcement can act, even though magistrates ordinarily keep warrants sealed until after they are returned executed. The decision to seek a search warrant fosters transparency values in significant ways by bringing judicial oversight into a criminal investigation early on. ${ }^{89}$ And it is not simply that the warrant requirement compels law enforcement to obtain permission from a separate branch of government: it also imposes substantive and procedural obligations to identify both the reason for the search (by giving probable cause) and the result of the search (by returning the executed warrant with an inventory of what was seized).

The fact that a search has occurred is fairly open to the public as well. Other witnesses might observe the search taking place. Even if not, the search warrant itself is typically a matter of public record. ${ }^{90}$ The fact that a search has occurred, then, is ordinarily revealed to a broad audience shortly after it happens. But public knowledge can be much richer: disclosure of search warrant records may establish the reason why an individual was searched and, more specifically, what was searched or taken.

This is, of course, a highly stylized description of the ways that Fourth Amendment doctrine requires disclosure of certain kinds of information. There are plenty of exceptions to these principles. When officers search a home, they might reasonably determine that announcing themselves would aggravate, not mitigate, the risk of violence. ${ }^{91}$ If the search occurs when the occupant is not home, the Federal Rules of Criminal Procedure require that notice be given and an inventory be left. ${ }^{92}$ However, so-called "sneak-and-peek" warrants permit law enforcement to conduct a search but delay notice to the target for a period of thirty days or more. ${ }^{93}$

88. Id. at 498 ("The defendants claimed a right, under precedents, to force persons houses, break open escrutores, seize their papers, [and] upon a general warrant, where no inventory is made of the things thus taken away, and where no offenders names are specified in the warrant, and therefore a discretionary power given to messengers to search wherever their suspicions may chance to fall.”).

89. See Pozen, supra note 34 , at 308.

90. Bloch-Wehba, supra note 15, 173-74.

91. Wilson v. Arkansas, 514 U.S. 927, 936 (1995) ("[L]aw enforcement interests may also establish the reasonableness of an unannounced entry.").

92. FED. R. CRIM. P. 41(f)(1)(D).

93. 18 U.S.C. § 3103a(b); see Jennifer Daskal, Notice and Standing in the Fourth Amendment: Searches of Personal Data, 26 WM. \& MARY BILL RTS. J. 437, 442 (2017); Jonathan Witmer-Rich, The Fatal Flaws of the "Sneak and Peek" Statute and How to Fix It, 65 CASE W. RSRV. L. REV. 121 (2014). 
Perhaps most significantly, Fourth Amendment doctrine has shifted in ways that limit the protections outlined in the preceding paragraphs. The numerous exceptions and carveouts to the so-called "warrant requirement" have led rueful commentators to liken it to "a piece of Swiss cheese." 94 Relying on the warrant requirement to ensure transparency in a world in which most searches are warrantless seems like fragile reassurance indeed. ${ }^{95}$ Moreover, to the extent these presumptions are made meaningful by the existence of potential remedies, including the exclusionary rule or civil damages, the vanishing availability of exclusion and the expansion of qualified immunity call those remedies into question. ${ }^{96}$

\section{Visibility to Whom?}

As the above discussion begins to outline, the scenarios also distinguish between different figures to whom information might be disclosed - magistrates, the targets of a search, and the general public. Disclosing a search warrant application to a neutral magistrate before it is executed is an integral aspect of Fourth Amendment protections; disclosing it to the target of a search or to the general public before the search occurs is virtually unprecedented. ${ }^{97}$ The result is that, while policing may be more secretive than in past eras, changes in policing practice may also have made transparency litigation a more feasible accountability strategy.

The circuit courts have disagreed about whether the lack of notice is a constitutional issue or simply a violation of the criminal rules. U.S. v. Freitas, 800 F.2d 1451, 1456 (9th Cir. 1986) (holding that notice was required to render search constitutional). Given the "heavy costs" of excluding evidence, it is perhaps not surprising that most courts of appeal, including the Second, Fourth, and Seventh Circuits, have concluded that lack of notice is not a constitutional issue at all, but rather simply a violation of the criminal rules. See Jonathan Witmer-Rich, The Rapid Rise of Delayed Notice Searches, and the Fourth Amendment "Rule Requiring Notice," 41 PEPP. L. REV. 509, 579-80, 579 n. 397 (arguing the claim that notice is "not part of the Fourth Amendment at all" is "overstated," and citing cases).

94. Oren Bar-Gill \& Barry Friedman, Taking Warrants Seriously, 106 Nw. U. L. REV. 1609, 1610-11 (2012); see also William J. Stuntz, Warrants and Fourth Amendment Remedies, 77 VA. L. REV. 881, 882 (1991) ("[I]n practice warrants are the exception rather than the rule.").

95. Bar-Gill \& Friedman, supra note 94, at 1666 ("The little data that exists affirms the suspicion that warrants are the exception rather than the norm."); BARRY FRIEDMAN, UNWARRANTED: POLICING WITHOUT PERMISSION 7 (2017) ("In a country of just over 300 million people, a rough analysis suggests state and local police conduct more than 8 million searches annually of pedestrians and automobiles alone.”); Frank G. Remington, Lawrence P. Tiffany, Donald M. Mcintyre \& Daniel L. Rrotenberg, Detection of Crime: Stopping and Questioning, Search and Seizure, ENCOURAGEMENT AND ENTRAPMENT 99-101, 101 n.8 (1967) (describing reliance on search warrants as rare).

96. Bar-Gill \& Friedman, supra note 94, at 1650-51 (describing the relationship between Fourth Amendment standards and remedies).

97. See, e.g., Zurcher v. Stanford Daily, 436 U.S. 547, 566-67 (1978), superseded by statute, 42 U.S.C. $\S 2000 \mathrm{aa}$ (a), (b) (declining to impose an obligation of "prior notice and hearing" when police execute a search warrant at a newsroom). 
First, the "neutral and detached magistrate" plays a critical role in checking and cabining police discretion. ${ }^{98}$ Ex ante disclosure to a magistrate may serve an instrumental goal: social science research suggests that when police are obligated to seek a warrant before conducting a search, they reach "better decisions," either because they are more aware of the potential consequences of the search or because they express their reasoning more effectively. ${ }^{99}$

But the ex ante judicial review anticipated by the warrant requirement is doubly important to visibility. By requiring judicial review before a search is executed, the warrant requirement involves a second branch of government in essential decision-making about a criminal investigation and thus limits secrecy within the government itself. ${ }^{100}$ As David Pozen suggests, the warrant requirement can make secrecy shallower: one function of the Fourth Amendment's warrant requirement is to "ensure[] that investigative secrecy will be moved from deeper to shallower before the moment when the search or seizure actually takes place" by involving the judiciary as a check on the executive branch. ${ }^{101}$ This secrecy-minimizing rationale holds true even if magistrates are biased toward law enforcement and inclined to approve search warrants or give them minimal scrutiny. ${ }^{102}$ Without an ex ante warrant requirement, courts would lack any knowledge of or involvement in criminal investigations until a defendant moves to suppress evidence. ${ }^{103}$

Second, the target of a search is equally important in Fourth Amendment doctrine, although less favored. Most Fourth Amendment cases are presented by defendants seeking to suppress the fruits of a search. ${ }^{104}$ Knowing that you were the target of a search is vital to making out a Fourth Amendment claim, even if it is not always sufficient to create standing. ${ }^{105}$ This is why parallel

98. Johnson v. United States, 333 U.S. 10, 14 (1948); see also Henry v. United States, 361 U.S. 98, 100 (1959) (describing the Fourth Amendment's probable cause requirement as replacing "police control" with "judicial control").

99. Bar-Gill \& Friedman, supra note 94, at 1638-42.

100. Pozen, supra note 34, at 308; see also Stuntz, supra note 94, at 890 (writing that the warrant process is unique not because it provides a neutral decisionmaker - which ex post review does as wellbut because of the "timing of the magistrate's decision" before the search takes place).

101. Pozen, supra note 34, at 308. Pozen, following Rubenfeld, further observes that the idea of deep secrecy "threatens not only the rule of law but also the sense of personal security that comes with living in a society governed by the rule of law." Id. at 309.

102. Bar-Gill \& Friedman, supra note 94, at 1639-40 (documenting concerns about "rubber stamp" magistrates).

103. Id. at 1651-52 (describing how the ex post suppression model involves judges fairly late in the game).

104. See Shima Baradaran, Rebalancing the Fourth Amendment, 102 GEO. L.J. 1, 4 (2013) ("[T] he rights of all to be free from police intrusion are protected by an individual with contraband she seeks to suppress .... [B] ecause the harmed party is identified as a criminal at the outset, the balance starts skewed in favor of the government.").

105. Rakas v. Illinois, 439 U.S. 128, 148 (1978) (holding that defendants with neither a "property nor a possessory interest" in the thing searched or seized lacked standing to invoke the exclusionary rule); see also Gray, supra note 13, at 88 ("[B] eing a target is neither necessary nor sufficient to establish eligibility to raise a Fourth Amendment claim."). 
construction - the practice of "laundering evidence in order to avoid court review of its actual provenance"-creates Fourth Amendment problems: it conceals the fact of a search from the target, minimizing the possibility that the target can raise a Fourth Amendment claim. ${ }^{106}$

And third, although the figure of the general public is rarely explicitly discussed in Fourth Amendment jurisprudence, it is present in practice. Both the warrant requirement and the exclusionary rule operate to bring the public into criminal investigations in underappreciated ways. Although search warrants are issued ex parte, they are usually filed with the clerk after a search is executed. ${ }^{107}$ Moreover, the dominance of the exclusionary rule as a Fourth Amendment remedy means the Fourth Amendment is enforced in pretrial hearings, which the public generally has a right to access. ${ }^{108}$ More generally, courts considering Fourth Amendment claims frequently seek to integrate the broader interests of society into their analyses of the defendant's privacy rights and the government's interests. ${ }^{109}$ For example, when the Supreme Court interprets the exclusionary rule as the "primary remedy" to vindicate Fourth Amendment rights, it emphasizes the need to apply the rule only where it "result[s] in appreciable deterrence." 110 The Court's deterrence rationale operates to "protect the innocent," $" 111$ those who will never be charged with a crime - and will therefore never be able to suppress evidence in their own criminal prosecutions.

\section{Visibility at What Time?}

The foregoing discussion also gestures to a third important aspect of Fourth Amendment visibility: when do transparency-enhancing interventions take place? The obvious first step in many cases is at the warrant stage, which takes a step to minimize law enforcement secrecy while an investigation is still ongoing. ${ }^{112}$ But because search warrants are, today, the exception rather than the rule, ${ }^{113}$ many cases will fail to deliver the ex ante transparency search warrants otherwise promise. Nonetheless, transparency is rarely delayed for long. In cases

106. Patrick Toomey \& Brett Max Kaufman, The Notice Paradox: Secret Surveillance, Criminal Defendants, \& the Right to Notice, 54 SANTA ClARA L. REV. 843, 863-64 (2014) (describing how the government can avoid suppression of evidence by engaging in parallel construction).

107. See FED. R. CRIM. P. 41.

108. Press-Enterprise Co. v. Super. Ct. of Cal., 478 U.S. 1, 10 n.3 (1986).

109. See Baradaran, supra note 104, at 39-43 (arguing that courts generally ignore relevant data about societal factors in assessing whether to suppress evidence).

110. United States v. Leon, 468 U.S. 897, 909 (1984) (quoting United States v. Janis, 428 U.S. 433, 454 (1976)).

111. Elkins v. United States, 364 U.S. 206, 218 (1960), (quoting Brinegar v. United States, 338 U.S. 160, 181 (1949) (Jackson, J., dissenting)).

112. Pozen, supra note 34, at 308; Stuntz, supra note 94.

113. Bar-Gill \& Friedman, supra note 94, at 1611; see also Pozen, supra note 34, at 308 (arguing that the warrant exceptions "do not necessarily undermine" the transparency-enhancing potential of the warrant requirement because most of the exceptions are unlikely "to have been preceded by deep investigative secrecy"). 
that involve warrantless searches, transparency frequently comes contemporaneously with the search itself. ${ }^{114}$

Even when transparency is achieved only after a search takes place, as the office-search scenario suggests, it is early enough to allow defendants to move to suppress and thereby vindicate their Fourth Amendment rights. In other words, when a defendant raises a notice issue in the context of a suppression hearing, the law enforcement action being challenged is hardly a secret. ${ }^{115}$ If, as Sissela Bok suggests, a secret is something "intentional[ly] concealed," a secret search litigated at a suppression hearing is not a secret at all: it has been laid bare to the defendant and the public. ${ }^{16}$ Challenges to truly secret searches, conversely, will almost never be presented in suppression hearings, because a defendant will not know that a secret search has occurred. ${ }^{117}$

The limited duration of secrecy in these paradigmatic cases, in turn, also suggests that the value of requiring notice as a constitutional matter is minimal. Rather than having been permanently harmed by a lack of notice, defendants have the information they need to understand that they have been searched - and to challenge the constitutionality of those searches. Indeed, the procedural background of most of the Court's Fourth Amendment jurisprudence, which results from motions to suppress in criminal cases, confirms that defendants do become aware that their homes or property have been searched, even if it is after the fact. As a practical matter, the lack of notice may not matter to targets of searches who ultimately become criminal defendants, because defendants would ordinarily receive notice during the pendency of a criminal case and would therefore be able to move to suppress the evidence.

\section{The Challenge of Programmatic Policing}

Today, police often initially confront individuals through pedestrian or vehicle stops - routine, low-level encounters that are not a secret. ${ }^{118}$ Indeed, the

114. See, e.g., Riley v. California, 573 U.S. 373 (2014) (search of phone incident to lawful arrest).

115. See Pozen, supra note 34, at 271 ("[T] he depth of a secret decreases to the extent that members of the community, including their representatives in government, understand that information is being concealed from them, the basic contours of that information, and how to go about discovering what it is.").

116. Sissela BoK, SeCRETS: ON THE ETHICS OF CONCEALMENT AND REVELATION 9 (Vintage Books 1989).

117. See, e.g., Brinegar v. United States, 338 U.S. 160, 181 (1949) (Jackson, J., dissenting) ("There may be ... many unlawful searches of homes and automobiles of innocent people which turn up nothing incriminating, in which no arrest is made, about which courts do nothing, and about which we never hear.").

118. Eric J. Miller, Encountering Resistance: Contesting Policing and Procedural Justice, 2016 U. CHI. Legal F. 295, 299-300 (2016) ("Police encounters are where the public engages most often and most profoundly with the police. These encounters can take a variety of forms, from the benign to the fatal."); G. Marcus Cole, Dean G. Marcus Cole: 'I Am George Floyd. Except, I Can Breathe. And I Can Do Something.,' U. Notre Dame L. SCH.: News (June 8, 2020), https://law.nd.edu/newsevents/news/dean-g-marcus-cole-i-am-george-floyd-except-i-can-breathe-and-i-can-do-something/ 
visibility of these encounters, and the ways in which they routinize police violence against Black people, in particular, fuel the ongoing uprisings against police violence and repression. In spite of this visibility, warrantless and "programmatic" policing techniques have also strained existing accountability mechanisms for searches and seizures. ${ }^{119}$ Nowhere is this clearer than in the context of the "Stop, Question, and Frisk" (SQF) strategy deployed in urban police departments.

SQF emerged as a result of the Supreme Court's decision in Terry v. Ohio, which held that law enforcement officers may briefly stop and frisk individuals for weapons based on a reasonable suspicion that the individual is armed and dangerous. ${ }^{120}$ Even before Terry, the practice of stopping and frisking individuals was decades old. ${ }^{121}$ But the Terry Court blessed the practice, recentering "reasonableness" as a key standard for law enforcement interactions with members of the public. ${ }^{122}$ In deemphasizing the more stringent "probable cause" standard, Terry permitted law enforcement to rely instead on a standard that is broad, flexible, and subjective. ${ }^{123}$ Yet Terry also acknowledged the possibility that the tactic it permitted would have wider social effects, particularly for non-White people. Expressing some concern about the "wholesale harassment" of minority groups, the Court nonetheless concluded that the practice was constitutional. ${ }^{124}$ The "explicit racial component" of police discretion, which marked "racial incongruity" with one's surroundings as suspicious, went unacknowledged. ${ }^{125}$

[https://perma.cc/X77B-VEKW] ("The police officer was intent on nothing more than humiliating and emasculating me in front of my small children, hoping to provoke me to respond. At that moment, I remember thinking that the most important thing I could do for my sons was to survive the encounter."); Peart, supra note 70.

119. By "programmatic" policing, I mean law enforcement tactics that do not proceed from the identification of an individual crime or suspect, but rather those aimed at "a broad body of the people" to deter or prevent crime. Barry Friedman \& Cynthia Benin Stein, Redefining What's "Reasonable": The Protections for Policing, 84 GEO. WASH. L. Rev. 281, 286-87 (2016); see also Renan, supra note 57, at 1042 (defining "programmatic" surveillance as being "designed en masse . . . through administrative policies").

120. Terry v. Ohio, 392 U.S. 1, 27 (1968).

121. See LaFave, supra note 72 , at 42 (describing stop-and-frisk as a "time-honored police procedure" that had been neglected by the courts and scholars).

122. See Terry, 392 U.S. at 27.

123. Id. at 30 (emphasizing that an officer may rely on experience and intuition in justifying their decision to stop and frisk an individual); Tracey Maclin, Terry v. Ohio's Fourth Amendment Legacy: Black Men and Police Discretion, 72 ST. JOHN's L. REV. 1271, 1278 (1998) (describing how the "malleable" Terry standard expanded police discretion, with disproportionate effects on black men).

124. Terry, 392 U.S. at 14-15; see also Maclin, supra note 123, at 1285 (arguing that, although Terry "seems to recognize that race matters to the Fourth Amendment," it "clearly occupied a subordinate position to the Court's overriding concern about police safety and violent crime").

125. Jeffrey Fagan \& Garth Davies, Street Stops and Broken Windows: Terry, Race, and Disorder in New York City, 28 FORDHAM URB. L.J. 457, 460 n.17 (2000) ("Terry was African American, McFadden was white. McFadden's 'professional judgment' concerning Terry was based on [Terry's presence] outside [of a typically] African-American [neighborhood].”); see also I. Bennett 
While Terry seemingly expanded Fourth Amendment coverage, it reduced law enforcement accountability. Terry extended Fourth Amendment scrutiny to a broader range of interactions between individuals and police, rejecting the idea that only the most formal of searches and seizures could infringe individual rights as "simply fantastic." ${ }^{126}$ Nonetheless, this transformation strained the prevailing transparency norms. Terry's conclusion that street encounters required no search warrant removed ex ante judicial review from the equation, and with it went a key opportunity for disclosure and oversight. ${ }^{127}$ As Wayne LaFave characterized stop-and-frisk in the immediate aftermath of Terry, it was not a "dark secret" - everybody knew about it — but the procedural and political realities of its use rendered it "low-visibility" in the sense that defining or curbing its use was not a political priority. ${ }^{128}$

Terry explicitly focused on the ex ante understanding of the police officer in a discrete encounter with an individual. ${ }^{129}$ But SQF gained traction throughout the 1990s and 2000s as a key programmatic component of urban policing based on "Broken Windows," "zero tolerance," or "order maintenance policing."130 The core principle of Broken Windows is that "disorder and crime are usually inextricably linked, in a kind of developmental sequence." 131 Broken Windows theory, therefore, encouraged police departments to concentrate their resources in areas of high disorder and granted departments broad discretion in determining exactly what "disorder" meant. ${ }^{132}$ Police departments quickly identified poor urban neighborhoods, which were frequently home to a predominantly Black and Latinx population, as the primary targets for "order maintenance" priorities:

Capers, Policing, Race, and Place, 44 HARV. C.R.-C.L. L. REV. 43, 68 (2009) ("[L]aw-abiding minorities in predominantly white communities face disproportionate stops by and encounters with the police, and law-abiding whites in minority communities face disproportionate stops by and encounters with the police. The officers in effect function as de facto border control, deciding who is scrutinized, stopped, questioned, or frisked." (footnotes omitted)).

126. Terry, 392 U.S. at 16-17; see also Akhil Reed Amar, Terry and Fourth Amendment First Principles, 72 ST. JOHN's L. REV. 1097, 1101 (1998) (describing the "“nonsearch' gambit”).

127. 392 U.S. at 20 ("[W]e deal here with an entire rubric of police conduct - necessarily swift action predicated upon the on-the-spot observations of the officer on the beat - which historically has not been, and as a practical matter could not be, subjected to the warrant procedure."); see also Scott E. Sundby, A Return to Fourth Amendment Basics: Undoing the Mischief of Camara and Terry, 72 MINN. L. REV. 383, 401-02 (1988) (describing how the Terry decision altered the "traditional yardstick of probable cause" and replaced it with "reasonable suspicion" as a "compromise").

128. LaFave, supra note 72, at 43.

129. See Andrew Guthrie Ferguson, Big Data and Predictive Reasonable Suspicion, 163 U. PA. L. REV. 327, 329 (2015) (describing reasonable suspicion as a "small data" doctrine).

130. Jeffrey Bellin, The Inverse Relationship Between the Constitutionality and Effectiveness of New York City "Stop and Frisk," 94 B.U. L. REV. 1495, 1504 \& n.39 (2014); Fagan \& Davies, supra note 125 , at $462,467$.

131. George L. Kelling \& James Q. Wilson, Broken Windows: The Police and Neighborhood Safety, ATLANTIC (Mar. 1982), https://www.theatlantic.com/magazine/archive/1982/03/brokenwindows/304465/ [https://perma.cc/VB5Z-FGTM].

132. Amna Akbar, National Security's Broken Windows, 62 UCLA L. REV. 834, 875 (2015) ("Broken windows theory, in its construction of the disorderly, the lawless, and the outsider as legitimate subjects of policing, rendered already vulnerable individuals as even more vulnerable to policing."). 
"aggressively enforcing laws against public drunkenness, loitering, vandalism, littering, public urination, panhandling, prostitution, and other minor misdemeanors." ${ }^{133}$ By singling out poor neighborhoods for Broken Windows interventions, police also embraced a place-based strategy that "target[ed] people of color, particularly African Americans, for stops and frisks." ${ }^{134}$ As the progenitors of Broken Windows put it in starkly racist language, a neighborhood might be transformed "to an inhospitable and frightening jungle" unless it addressed a range of threats: "rowdy children," "unattached adults," teens "in front of the corner store," littering, "inebriate[s]," panhandling. ${ }^{135}$ Stopping and frisking individuals was an essential element of success for a "quality of life" strategy designed to increase arrests and tickets for misdemeanors and other lowlevel offenses. ${ }^{136}$

The "programmatic" policing techniques that SQF exemplifies bring unique and disproportionate impacts to poor and minority communities, not just individuals. ${ }^{137}$ As Tracey Meares put it, SQF-and Broken Windows more generally - is "not simply a tool," but rather a program that shifts police inquiries from individual crimes to "suspicious characteristics" of whole communities, seen through a skewed, racialized lens. ${ }^{138}$ In light of the programmatic nature of $\mathrm{SQF}$, which is "carried out systematically, deliberately, and with great frequency," Terry's focus on the "individual, incident-level" approach seems to miss the point. ${ }^{139}$ Analyzing stops and frisks as discrete, individual incidents fails to appreciate how their "large scale and 'group-based' application" differs from the traditional, highly individualized model of policing. ${ }^{140}$ These

133. Bernard E. Harcourt, Reflecting on the Subject: A Critique of the Social Influence Conception of Deterrence, the Broken Windows Theory, and Order-Maintenance Policing New York Style, 97 MiCH. L. REV. 291, 301 (1998). Notably, while the original proponents of Broken Windows emphasized "alternatives to arrest and prosecution," NYPD abandoned these alternatives, focusing instead on boosting arrests. Fagan \& Davies, supra note 125, at 471.

134. Anthony C. Thompson, Stopping the Usual Suspects: Race and the Fourth Amendment, 74 N.Y.U. L. REV. 956, 957 (1999); see also Brett G. Stoudt, Michelle Fine \& Madeline Fox, Growing Up Policed in the Age of Aggressive Policing Policies, 56 N.Y.L. SCH. L. REV. 1331, 1347 (2012) (differentiating between, on the one hand, individual racially motivated stops and, on the other, racially disparate impact of the SQF program).

135. Kelling \& Wilson, supra note 131.

136. Issa Kohler-Hausmann, Managerial Justice and Mass Misdemeanors, 66 STAN. L. REV. 611, 631-32 (2014); Fagan \& Davies, supra note 125, at 477 ("[S]tops were disproportionately concentrated in the city's poorest neighborhoods, neighborhoods with high concentrations of racial minorities.").

137. See Monica C. Bell, Police Reform and the Dismantling of Legal Estrangement, 126 YALE L.J. 2054, 2139-40 (2017) (framing the "program" as "bigger than systematic Terry stops-and-frisks of young African American and Latino men," but rather "endemic to policing itself").

138. Tracey L. Meares, Programming Errors: Understanding the Constitutionality of Stop-andFrisk as a Program, Not an Incident, 82 U. CHI. L. REV. 159, 168-69 (2015).

139. Id. at 164.

140. Aziz Z. Huq, The Consequences of Disparate Policing: Evaluating Stop and Frisk as a Modality of Urban Policing, 101 MINN. L. REV. 2397, 2402 (2017); see also Meares, supra note 138, at 168-69 (noting the programmatic nature of the policies); Bernard E. Harcourt \& Tracey L. Meares, 
"ecological" harms, as Aziz Huq has put it, are a poor fit for Fourth Amendment doctrine's "transactional frame." 141

SQF became a key scholarly case study of programmatic policing not just because it vividly illustrated the impact of policing on entire communities but also because the traditional Fourth Amendment remedy of exclusion proved wildly inadequate to address its harms. Communities struggled to hold police accountable for this practice that was occurring in public, yet somehow out of the frame of oversight or accountability. As the Terry Court had predicted, the exclusionary rule would be "powerless to deter invasions of constitutionally guaranteed rights where the police either have no interest in prosecuting or are willing to forgo successful prosecution in the interest of serving some other goal." 142

In the context of SQF, one result of Terry was to remove large swaths of police conduct from judicial oversight altogether, rendering significant aspects of policing invisible to the courts. ${ }^{143}$ According to the Attorney General's report, only 6 percent of all SQF stops in New York City resulted in an arrest, and 6 percent resulted in a summons. ${ }^{144}$ This left relatively few individuals who could have moved to suppress evidence on the basis of an unlawful stop and frisk. The result, as this Article demonstrates in the Section that follows, was that activists, individuals, and organizations partly turned away from the traditional avenues of vindicating Fourth Amendment rights and instead strategically deployed transparency litigation designed to bring SQF into the spotlight and boost its political salience.

III.

\section{CRIMINAL PROCEDURE's SHADOW DOCKET}

Along nearly every axis, the nature of policing has changed dramatically, calling into question the archetypal contours of Fourth Amendment doctrine. The realities of modern policing programs and technologies show that the warrant requirement and exclusionary rule are ineffective safeguards against unchecked, opaque policing. New technologies of surveillance have strengthened police departments' ability to engage in the "low-visibility" strategies first implemented with stop and frisk and indeed have deepened the shadows around these practices. In short, against the consensus view that policing ought to be

Randomization and the Fourth Amendment, 78 U. CHI. L. REV. 809, 834-35 (2011) (overviewing suspicionless search programs).

141. Huq, supra note 140, at 2402, 2450; Daryl J. Levinson, Framing Transactions in Constitutional Law, 111 YALE L.J. 1311, 1314 (2002).

142. Terry v. Ohio, 392 U.S. 1, 14-15 (1968).

143. See 392 U.S. at 13 ("[I]n our system evidentiary rulings provide the context in which the judicial process of inclusion and exclusion approves some conduct as comporting with constitutional guarantees and disapproves other actions by state agents.")

144. Floyd v. City of New York, 959 F. Supp. 2d 540, 575 (S.D.N.Y. 2013) (discussing the NYPD's "hit rate"). 
more democratic, more accountable, and more transparent, significant evidence suggests that new technology and shifts in Fourth Amendment doctrine have undermined these values. ${ }^{145}$

This Section explores one response: the development of what I call criminal procedure's "shadow docket." Criminal procedure is heavily constitutionalized. ${ }^{146}$ Increasingly, however, oversight institutions, individuals, and civil society organizations have turned to a "shadow docket" of transparency litigation that does not resolve the constitutional merits of any law enforcement practice but rather functions as a mechanism to access the data and information critical to understanding policing practices. Many advocates are deploying a dual strategy of transparency litigation in tandem with substantive Fourth Amendment claims to expose programmatic surveillance and policing technology.

If I am correct that the turn toward transparency litigation has been prompted by deficiencies in existing constitutional, statutory, and regulatory frameworks for police accountability, then the "shadow docket" has flourished because it is one of the few effective strategies at extracting critical information from law enforcement. But the turn toward transparency litigation to promote police accountability has also led courts to develop a body of caselaw outside of the traditional framework of constitutional law that, nonetheless, is salient to criminal procedure. These efforts, I show, are part of a multiprong strategy to reform law enforcement and subject it to democratic control.

\section{A. Transparency Advocacy Challenging Programmatic Policing}

\section{Stop, Question, Frisk}

Early in the morning on February 4, 1999, four New York Police Department (NYPD) officers killed Amadou Diallo, a twenty-two-year-old unarmed West African immigrant, in a fusillade of forty-one shots outside his home in the Bronx as he fumbled with his wallet. ${ }^{147}$ The officers were stopping Diallo because he ostensibly resembled a rape suspect, but the stop immediately went wrong when they interpreted his wallet as a weapon. ${ }^{148}$ The officers were members of the Street Crimes Unit (SCU), an "elite"-and overwhelmingly

145. See supra Part I.B (articulating the consensus view).

146. William J. Stuntz, Substance, Process, and the Civil-Criminal Line, 7 J. CONTEMP. LEGAL ISSUES 1, 7-8 (1996) (noting some of the perverse incentives created by the constitutionalization of criminal procedure).

147. Michael Cooper, Officers in Bronx Fire 41 Shots, and an Unarmed Man Is Killed, N.Y. TIMES, Feb. 5, 1999, at A1, B5, https://www.nytimes.com/1999/02/05/nyregion/officers-in-bronx-fire41-shots-and-an-unarmed-man-is-killed.html [https://perma.cc/S4JD-5AXQ].

148. Robert D. McFadden \& Kit R. Roane, U.S. Examining Killing of Man in Police Volley, N.Y. TIMES, Feb. 6, 1999, at A1, B6, https://www.nytimes.com/1999/02/06/nyregion/us-examining-killingof-man-in-police-volley.html [https://perma.cc/N8BC-X8QL]. 
White-squad of almost four hundred officers based at Randall's Island that focused on searching for guns as well as other dangers to New York residents. ${ }^{149}$

Public outcry was enormous and immediate. ${ }^{150}$ Local, federal, and state officials made clear their intent to investigate the broader circumstances surrounding Diallo's murder. ${ }^{151}$ Quickly, investigators turned toward the SCU's use of "stop and frisk" tactics and other "lower-level" encounters between civilians and police. ${ }^{152}$ Barely a month after Diallo's murder, a group of Black and Latinx plaintiffs filed Daniels $v$. City of New York, the first case to challenge NYPD's stop and frisk program. ${ }^{153}$

SQF underscores how reform efforts have deployed transparency law and litigation in tandem with substantive constitutional and civil rights claims to subject police practices to public scrutiny and democratic oversight. In addition to the constitutional merits of SQF, transparency about the NYPD's practices became a key focal point for efforts to hold the department accountable. Both understanding and challenging SQF required extensive access to data, which investigators and legislators quickly demanded NYPD provide. NYPD "scrambl[ed]" to compile data regarding the SQF program, hiring temporary workers to comb through all its stop-and-frisk reports-generated on a form called the UF-250 - in order to produce them to investigators and oversight bodies. ${ }^{154}$ Attorney General Eliot Spitzer, who conducted his own investigation of the program, threatened to subpoena NYPD for "thousands of documents" when the city refused to hand data over voluntarily. ${ }^{155}$ In the end, NYPD provided UF-250 data from 1994 through April 1999 to federal investigators. ${ }^{156}$ The centrality of data to effective oversight also prompted the legislature to act.

149. David Kocieniewski, Success of Elite Police Unit Exacts a Toll on the Streets, N.Y. TIMES, Feb. 15, 1999, at A1, B5, https://www.nytimes.com/1999/02/15/nyregion/success-of-elite-police-unitexacts-a-toll-on-the-streets.html [https://perma.cc/88AB-GSD6].

150. Katherine E. Finkelstein, Protests in Police Killing of Diallo Grow Larger, and More Diverse, N.Y. TIMES, Mar. 25, 1999, at B12, https://www.nytimes.com/1999/03/25/nyregion/protestsin-police-killing-of-diallo-grow-larger-and-more-diverse.html [https://perma.cc/WFA6-F582].

151. Michael Cooper, Street Searches by City's Police Lead to Inquiry, N.Y. TIMES, Mar. 18, 1999, at A1, B6, https://www.nytimes.com/1999/03/18/nyregion/street-searches-by-city-s-police-leadto-inquiry.html [https://perma.cc/3H6C-2LW6].

152. Eliot Spitzer, The NeW York City Police Department's “Stop \& Frisk”

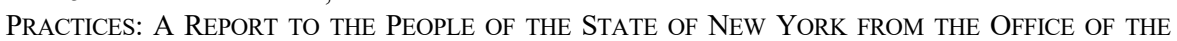
AtToRney General 8 (1999); Benjamin Weiser, Frisking Policy of the Police Faces Scrutiny, N.Y. TIMES, Mar. 19, 1999, at B1, B5, https://www.nytimes.com/1999/03/19/nyregion/frisking-policy-ofthe-police-faces-scrutiny.html [https://perma.cc/X39M-76TM].

153. Daniels v. City of New York, 75 F. Supp. 2d 154 (S.D.N.Y. 1999).

154. Larry Celona, NYPD To Bare 'Stop \& Frisk' Data, N.Y. Post (Apr. 12, 1999) https://nypost.com/1999/04/12/nypd-to-bare-stop-exclusive/ [https://perma.cc/H2KJ-GBVE].

155. Kit R. Roane, Spitzer Threatens Subpoena for Police Data on Frisking, N.Y. TIMES, May 16, 1999 (§ 1), at 39, https://www.nytimes.com/1999/05/16/nyregion/spitzer-threatens-subpoena-forpolice-data-on-frisking.html [https://perma.cc/XRB3-Y7P9]. The city ultimately backed down. Kit R. Roane, Giuliani Agrees to Give the State Police Documents on Frisking, N.Y. TIMES, May 26, 1999 $(\S \mathrm{B})$, at 5, https://www.nytimes.com/1999/05/26/nyregion/giuliani-agrees-to-give-the-state-policedocuments-on-frisking.html [https://perma.cc/R2P5-KDRH].

156. Daniels v. City of New York, 200 F.R.D. 205, 207 (S.D.N.Y. 2001). 
In 2001, the New York City Council enacted the Police Reporting Law, which required NYPD to produce data regarding the department's SQF program on a quarterly basis. ${ }^{157}$

Access to SQF data also proved integral to the stop and frisk litigation. In January 2000, the Daniels parties agreed that the NYPD would produce the UF250 database to plaintiffs subject to certain nondisclosure provisions. ${ }^{158}$ When Daniels settled in 2003, the settlement agreement included the critical component that NYPD continue to use the UF-250 database to track all SQF activity - and continue to disclose the data, in redacted form, to the plaintiffs' counsel on a quarterly basis. ${ }^{159}$

Even after Daniels settled, SQF data continued to prove essential to mobilizing civil society organizations and the public for additional reforms to the SQF program. ${ }^{160}$ In February 2007, NYPD released statistics establishing that it had stopped, questioned, or frisked over half a million individuals. ${ }^{161} \mathrm{In}$ response to widespread negative blowback, NYPD then commissioned the RAND Corporation to write a report on racial bias in the SQF program. Relying on data from the NYPD's computerized UF-250 database, RAND concluded that the raw statistics "distort the magnitude and, at times, the existence of racially biased policing" and that "a large-scale restructuring" of the SQF program was "unwarranted." 162

But when the city council requested the UF-250 database to perform its own analysis, NYPD refused to grant it. ${ }^{163}$ In response, the New York Civil Liberties Union filed a Freedom of Information Law request (and then an Article 78 proceeding) seeking access to the UF-250 database. ${ }^{164}$ The City vigorously

157. N.Y.C. LOCAL LAW NO. 2001/055 (codified as amended at ADMIN. CODE tit. 14, ch. 1, § 14150).

158. Protective Order 9 2, Daniels v. City of New York, 138 F. Supp. 2d 562 (S.D.N.Y. 2001) (No. 99-CV-01695). The agreement went haywire when the plaintiffs certified a class, leading NYPD to seek a stay that would allow the agency to avoid producing the UF-250 database to the plaintiffs until it had exhausted its appeal of the class certification to the Second Circuit. 138 F. Supp. 2d at 564.

159. Stipulation of Settlement at 8, Daniels, 138 F. Supp 2d 562 (No. 99-CV-01695). In addition, NYPD agreed to engage in some public-facing outreach, including by engaging in several Joint Community Forums, presenting workshops at local high schools, and revising its "Understanding Your Rights" pamphlets. Id. at 9-10.

160. See Ariel E. Belen, New York City Joint Remedial Process on NYPD's Stop, QUESTION, AND FRISK, AND TRESPASS ENFORCEMENT POLICIES: FINAL REPORT AND RECOMMENDATIONS 43-45 (2018) ("[T]he UF-250 and the later-created UF-250 database have played a crucial role in the ability of actors outside of the NYPD, including the public, to assess the effectiveness and constitutionality of the NYPD's SQF practices over time.").

161. NYPD, NeW York POLICE DEPARTMENT (NYPD) STOP, QUeSTION, AND Frisk DATABASE, 2006 (2008).

162. GREG RidGEWAY, RAND CORP., ANALYSIS OF RACIAL DiSPARITIES IN THE NEW YORK POLICE DEPARTMENT'S STOP, QUESTION, AND FRISK PRACTICES, at xiv (2007).

163. Rocco Parascandola, New York Police Will Release Stop-Frisk Reports, MCClatCHY TRIB. BUS. NEWS (Jan. 25, 2008) (on file with author).

164. Verified Petition, N.Y.C.L. Union v. NYPD, No. 115154/07 (N.Y. Sup. Ct. Nov. 13, 2007). 
argued that disclosure of the UF-250 database would jeopardize security. ${ }^{165}$ Disclosing the database, the City argued, would enable a bad actor to reconstruct the patterns of police officers' movements and their "enforcement strategies" throughout the city. ${ }^{166}$ The court rejected the argument and ordered NYPD to release the database, noting that NYPD had already "provided copies of the database to at least two other outside organizations," including RAND. ${ }^{167}$

The dual strategy of seeking constitutional accountability at the same time as compelling data access embraced by challengers of stop-and-frisk in New York City has also gained traction elsewhere. In Philadelphia, for instance, the police department is subject to ongoing court-appointed monitoring due to its stop-and-frisk policy. ${ }^{168}$ In 2016, the city's Defender Association filed a lawsuit seeking access to more granular data about the Police Department's stop-andfrisk patterns. ${ }^{169}$

\section{Other "Broken Windows" programs}

Similar patterns also arise in other programmatic policing contexts. In early 2012, the New York Civil Liberties Union (NYCLU) filed an Article 78 petition seeking information about an NYPD program called "Operation Clean Halls" or the "Trespass Affidavit Program." 170 The program, which was decades old, enlisted private landlords to permit police officers to enter their buildings and arrest trespassers and loiterers. ${ }^{171}$ Two months later, NYCLU attorneys appeared in federal court in Ligon v. City of New York alongside attorneys from the Bronx Defenders and LatinoJustice PRLDEF, representing a class of plaintiffs challenging the program on the grounds that it violated the Fair Housing Act, the

165. The City claimed that the UF-250 database was exempt from disclosure because it implicated "non-routine criminal investigative techniques or procedures." Motion to Dismiss at 5, N.Y.C.L. Union v. NYPD, No. 115154/07 (N.Y. Sup. Ct. Jan. 17, 2008) (on file with author).

166. Id. at 6.

167. N.Y.C.L. Union v. NYPD, No. 115154/07, slip op. at 3 (N.Y. Sup. Ct. May 7, 2008) ("The NYPD has not offered any reason why the petitioner should be denied access to the same database which it has already shared with other outside organizations.”). As the FOIL proceeding was pending, Daniel Floyd and Lalit Clarkson filed a civil rights complaint in federal court alleging that NYPD had a widespread pattern and practice of improperly stopping and frisking people without reasonable suspicion. Complaint, Floyd v. City of New York, 959 F. Supp. 2d 668 (S.D.N.Y. 2013) (No. 08-CV01034).

168. Bobby Allyn, Stop-and-Frisk Abuses Ebb, but Report Says Some Philly Police Still Ignore Guidelines, WHYY (Dec. 7, 2017), https://whyy.org/articles/stop-frisk-abuses-ebb-report-says-phillypolice-still-ignore-guidelines/ [https://perma.cc/FBK6-ZCVG].

169. Bobby Allyn, Court Battle Looms over Philly Police Refusal to Turn over Stop-and-Frisk Records, WHYY (Jan. 7, 2016), https://whyy.org/articles/court-battle-looms-over-philly-police-refusalto-turn-over-stop-and-frisk-records/ [https://perma.cc/33WB-P6EN].

170. Verified Petition 8-9, N.Y.C.L. Union v. N.Y. Cnty. District Attorney, No. 12/100682 (N.Y. Sup. Jan. 21, 2012), 2012 WL 173498.

171. Julie Turkewitz, In New York, a 20-Year-Old Policy Suddenly Prompts a Lawsuit, THE ATLANTIC (May 1, 2012), https://www.theatlantic.com/national/archive/2012/05/in-new-york-a-20year-old-policy-suddenly-prompts-a-lawsuit/256584/ [https://perma.cc/QM8L-CA9R]. 
First Amendment, and the Fourth Amendment. ${ }^{172}$ Ligon was ultimately resolved in the same remedies opinion as Floyd v. City of New York. ${ }^{173}$

Transparency litigation has continued to play a critical role in exposing Broken Windows practices to public scrutiny up to the present moment. ${ }^{174}$ In July 2017, New York City Councilmember Rory Lancman introduced a bill to require NYPD to publish data on the number of arrests and summonses issued for subway fare evasion on a quarterly basis. ${ }^{175}$ The existing data, gleaned by public defender organizations who represented individuals accused of farebeating, showed widespread racial disparities. ${ }^{176}$ Lancman's bill, enacted in 2018 , required NYPD to begin publishing quarterly reports that included the total number of fare evasion arrests, disaggregated by district, transit station, and demographic information of the arrestee. ${ }^{177}$

But NYPD did not comply with the law's disclosure mandates, failing to publish relevant data regarding arrests at the vast majority of the city's 472 subway stations. ${ }^{178}$ In May 2018, Council Member Lancman, alongside the Community Service Society (CSS) - a nonprofit organization that advocates for poor New Yorkers - filed a Freedom of Information Law (FOIL) request seeking the data that NYPD had failed to publish. ${ }^{179}$ NYPD denied the request, arguing that releasing the statistical information Lancman and CSS sought—and which the Department was compelled by statute to disclose - would jeopardize public safety by permitting statistical analysis that "could be used to deduce the regular

172. Complaint at 50-51, Ligon v. New York, No. 12-cv-2274 (S.D.N.Y. Mar. 28, 2012), ECF No. 1.

173. Floyd v. City of New York, 959 F. Supp. 2d 668, 688 (S.D.N.Y. 2013).

174. See Guy Padula, Utah v. Strieff: Lemonade Stands and Dragnet Policing, 120 W. VA. L. REV. 469, 521 (2017) (situating fare evasion arrests within Broken Windows strategy); Anna Flagg \& Ashley Nerbovig, Subway Policing in New York City Still Has a Race Problem, MARSHALl ProJECT (Sept. 12, 2018), https://www.themarshallproject.org/2018/09/12/subway-policing-in-new-york-citystill-has-a-race-problem [https://perma.cc/UH9X-BVAS] (same).

175. N.Y.C. Council Int. No. 1664-A, 2017 Council, July 20 Meeting (N.Y.C. 2017) (enacted), https://legistar.council.nyc.gov/LegislationDetail.aspx?ID=3106792\&GUID=75B76B89-FD404CAF-978F-35D2F26EB913\&FullText=1 [https://perma.cc/3YZZ-XT8Z].

176. HAROLD STOLPER \& JEFF JONES, CMTY. SERV. SOC’Y, THE CRIME OF BEING SHORT \$2.75: POLICING COMMUNITIES OF COLOR AT THE TURNSTILE 2 (2017), https://smhttp-ssl58547.nexcesscdn.net/nycss/images/uploads/pubs/Fare_Evasion_FINAL_10_6_17_smaller.pdf [https://perma.cc/5ZUP-NC2S]. The report relied on data from the two public defender organizations in Brooklyn regarding all their clients who had been arrested on "Theft of Service" charges during 2016. The report concluded that "the greatest concentrations of theft of service arrests occur around subway stations nearest to the poorest and predominantly black census tracts." Id. at 4, 10.

177. N.Y.C. LOCAL LAW NO. 2018/047 (amending ADMIN. CODE tit. 14, § 14-172).

178. Josh Levitt, NYPD Disclosure of Enforcement Data Fails to Comply with Fare Evasion Reporting Law, N.Y.C. COUNCIL (Oct. 3, 2018), https://council.nyc.gov/rorylancman/2018/10/03/nypd-disclosure-of-enforcement-data-fails-to-comply-with-fare-evasionreporting-law/ [https://perma.cc/JUF3-WBK3].

179. Verified Petition, Lancman v. NYPD, No. $19 / 154329$ (N.Y. Sup. Ct. Apr. 26, 2019). A few months later, Lancman and CSS also filed a petition for mandamus, seeking to compel NYPD to comply with Local Law 47. Verified Petition, Lancman v. De Blasio, 2019 WL 1437894 (N.Y. Sup. Ct. 2019) (No. 18/158709). 
deployment of NYPD resources at various stations through New York City." 180 When Lancman filed an Article 78 proceeding to compel NYPD to disclose the information, the court rejected the City's argument as "speculative at best, and improbable at worst," and ordered the data disclosed. ${ }^{181}$

\section{B. Data-Driven Policing}

The SQF litigation exemplifies how the turn from "transactional" investigations based on individual suspicion to "programmatic" policing methods has strained public oversight mechanisms and required new ways of addressing transparency for Fourth Amendment activity. Law enforcement's shift toward data-driven policing strategies has further diminished its visibility. ${ }^{182}$ Unlike the classic Broken Windows modalities of policing - such as stops, frisks, and arrests - data-driven policing practices often do not directly implicate Fourth Amendment protections. ${ }^{183}$ While these techniques might sometimes be used to investigate individual crimes, they are at least as often used as "dragnets" intended to sweep up information about large segments of the public. ${ }^{184}$ And while challenges to the constitutionality of physical dragnets such as roadblocks, administrative searches, and drug testing have come to the Court, there is little guidance on how the Fourth Amendment might apply to data-driven policing. ${ }^{185}$ Although the Supreme Court in the recent cases of Jones and Carpenter ruled that pervasive, long-term location tracking is the subject of Fourth Amendment protection, it remains unclear how those decisions fit with the longstanding rule that searches of public information are not really "searches" at all. ${ }^{186}$

180. Verified Petition 47, Lancman v. NYPD, No. 19/154329 (N.Y. Sup. Ct. Apr. 26, 2019).

181. Lancman v. NYPD, No. 154329/2019, slip op. at 1 (N.Y. Sup. Ct. Sept. 23, 2019) (order granting petition in part), NYSCEF No. 24.

182. See Elizabeth E. Joh, The Undue Influence of Surveillance Technology Companies on Policing, 92 N.Y.U. L. REV. ONLINE 19, 36-37 (2017) (explaining how proprietary interests shield predictive policing technologies from public knowledge and transparency values).

183. See, e.g., Christopher Slobogin, Panvasive Surveillance, Political Process Theory, and the Nondelegation Doctrine, 102 GEO. L.J. 1721, 1723 (2014); Renan, supra note 57, at 1056 (noting the problems programmatic surveillance poses to a traditional, transaction-based Fourth Amendment framework).

184. Renan, supra note 57, at 1053 (noting that "generalized collection" can quickly transform into suspicion-based, targeted database searches); Christopher Slobogin, Government Dragnets, 73 LAW \& CONTEMP. PROBS. 107, 107-08 (2010) (describing "the power of the executive branch, on its own or on the basis of vague legislative authorization, to engage in large-scale intrusions into the citizenry's houses, persons, papers, and effects in the absence of probable cause"); Friedman \& Stein, supra note 119, at 303-04 (describing the widespread turn to "dragnet searches without cause").

185. Slobogin, supra note 184 , at 120 (suggesting that this is partly because many data-driven policing strategies occur in secret).

186. See United States v. Jones, 565 U.S. 400, 417 (2012) (Sotomayor, J., concurring) (questioning the application of the third party doctrine in the "digital age"); Carpenter v. United States, 138 S. Ct. 2206, 2216 (2018) ("[A] person has no legitimate expectation of privacy in information he voluntarily turns over to third parties." (quoting Smith v. Maryland, 442 U.S. 735, 743-44 (1979))); 1 
In light of these constitutional dynamics, transparency litigation is a critical avenue to understanding the implications of contemporary policing strategies. As documented in this Section, these efforts to expose modern policing technologies to scrutiny are part of a broader litigation and political strategy to shift the political discourse as well as the substantive rules that govern law enforcement investigations. ${ }^{187}$

\section{Gang Databases}

Gang policing - which one National Association for the Advancement of Colored People (NAACP) attorney called "the new stop and frisk"demonstrates how new policing techniques function opaquely and how a "shadow docket" of transparency litigation has emerged in response. ${ }^{188}$ Gang databases collect information about alleged members of criminal gangs for use by law enforcement and other agencies. Although gang database practices vary somewhat among jurisdictions, they tend to have some common features. First, individuals are usually neither notified that they have been included in a gang database nor given an opportunity to challenge a designation as a gang member or affiliate. ${ }^{189}$ Second, the criteria for inclusion tend to be unclear, and police departments have broad discretion to designate individuals as gang members. ${ }^{190}$ Third, many agencies tend to permit widespread sharing of information from the

WAYNE LAFAVE, SEARCH \& SEIZURE: A TREATISE ON THE FouRTh AMENDMENT $§ 2.7$ (g) (6th ed.), Westlaw (databased updated Sept. 2020) (discussing Fourth Amendment law as it relates to technological surveillance and suggesting possible ways the Jones and Carpenter decisions alter this body of law); see also Ric Simmons, From Katz to Kyllo: A Blueprint for Adapting the Fourth Amendment to Twenty-First Century Technologies, 53 HASTINGS L.J. 1303, 1325 n.99 (2002) ("[U]nder the analysis proposed in this article, facial recognition technology is no different from an officer comparing a photograph of a known criminal to the faces of people the officer passes in the street."). Wayne Logan and Andrew Ferguson have argued that when the police take action "on the basis of a database error," such as a false positive match in a facial recognition database, the Fourth Amendment's prohibition of "unreasonable" searches and seizures may be implicated. Wayne A. Logan \& Andrew Guthrie Ferguson, Policing Criminal Justice Data, 101 MiNN. L. REV. 541, 577 (2016); see also Michael L. Rich, Machine Learning, Automated Suspicion Algorithms, and the Fourth Amendment, 164 U. PA. L. REV. 871, 924-27 (2016) (suggesting that errors in automated suspicion algorithms may result in a Fourth Amendment suppression remedy if they were the result of deliberate, reckless, or grossly negligent misconduct).

187. Cf. Manes, supra note 17, at 518-19 (describing how efforts to shed light on the use of Stingray surveillance technology proceeded in tandem with efforts to constrain their use).

188. Marne Lenox, Assistant Couns., NAACP, Testimony on NYPD's Gang Takedown Efforts Before the N.Y.C. Council Comm. on Public Safety 3 (June 13, 2018) ("While the NYPD touts the declining number of police stops as evidence of its compliance with the law, the Department secretly continues to target, surveil, and catalog young men of color."), https://legistar.council.nyc.gov/LegislationDetail.aspx?ID=3506401\&GUID=43D779AF-FAC6-41229886-87F19EAE5CC6\&Options=\&Search= [https://perma.cc/8CA5-L2F6]; see also K. Babe Howell, Gang Policing: The Post Stop-and-Frisk Justification for Profile-Based Policing, 5 U. DENV. CRIM. L. REV. 1, 4-5 (2015) (arguing that aggressive gang policing emerged as a form of social and racial control after Floyd held SQF unconstitutional).

189. Howell, supra note 188, at 15.

190. Keegan Stephan, Conspiracy: Contemporary Gang Policing and Prosecutions, 40 CARDOZO L. REV. 991, 1015 (2018). 
databases with other law enforcement institutions. ${ }^{191}$ Finally, gang databases are often inaccurate and raise concern about potential impacts on free expression and association. ${ }^{192}$

As Professor Babe Howell has pointed out, gang policing-by-database "avoids both public and judicial scrutiny" by taking place in secret. ${ }^{193}$ Gang databases also tend to operate without rigorous public oversight. ${ }^{194}$ As a result, individuals and organizations have turned toward transparency law to lay the basis for a legal challenge to gang policing tactics.

In New York City, for instance, organizations have employed a strategic shift toward use of the State's FOIL to obtain critical information about gang policing. ${ }^{195}$ Although NYPD has repeatedly testified before the New York City Council in general terms about the Criminal Group Database, it has never made public the criteria that it uses in determining whether to include an individual. ${ }^{196}$ Nor has the city council compelled NYPD to do so. Even NYPD's definition of a "criminal group" is unclear. ${ }^{197}$ Accordingly, in 2018, the NAACP Legal Defense Fund and the Center for Constitutional Rights filed an Article 78 proceeding seeking to compel disclosure of records reflecting the criteria for inclusion in the gang database, demographic information for individuals included in the database, and documents about the relationship between the gang

191. Mick Dumke, Chicago's Inspector General Finds the City's Gang Database Is Riddled with Errors, PROPUBLICA (Apr. 11, 2019), https://www.propublica.org/article/chicago-police-departmentgang-database-inspector-general-report [https://perma.cc/U2CK-TV7X] (reporting that Chicago's database was widely accessible to hundreds of other law enforcement agencies - so many that CPD couldn't even list them all).

192. See Noah Hurowitz, NYPD's Secret Gang Database Filled With 'Garbage, 'Advocates Say, DNAINFO (Oct. 19, 2017), https://www.dnainfo.com/new-york/20171019/civic-center/nypd-gangdatabase-legal-aid-brooklyn-defenders-foil-request/ [https://perma.cc/3MQC-92VL]; Rebecca A. Hufstader, Note, Immigration Reliance on Gang Databases: Unchecked Discretion and Undesirable Consequences, 90 N.Y.U. L. REV. 671, 673 (2015) (describing a "developing federal policy of relying on gang databases to determine immigration benefits and burdens"); Stephan, supra note 190, at 1014 ("[O]nly one state [California] has any statutory mechanism to challenge being on a gang database or to be removed from a gang database."); Shiu-Ming Cheer, NILC and Other Orgs Work to Shed Light on Gang Databases and Fight the Criminalization of People of Color, NAT'L IMMIGR. L. CTR. (July 14, 2016), https://www.nilc.org/2016/07/14/9988/ [https://perma.cc/2NW8-TFSK] (documenting consequences of presence in gang databases, including "increased probability of criminal conviction, sentence enhancements, loss of employment, and eviction from public housing"); see also Joshua A.T. Fairfield \& Erik Luna, Digital Innocence, 99 CoRNELl L. REV. 981, 986 (2014) (positing that digital evidence might be used to exonerate defendants).

193. Howell, supra note 188, at 4; see also Stephan, supra note 190, at 1014 ("In some states, everything about gang databases is specifically exempt from freedom of information requests.").

194. See Stephan, supra note 190, at 1014 (noting that few states have adopted affirmative legislation authorizing police use of gang databases).

195. Hurowitz, supra note 192.

196. See id.; see also Hearing on Int. 1645-2019 et al. Before the N.Y.C. Council Comm. on Public Safety, 2019 Council, June 27 Meeting 31-33 (N.Y.C. 2019) (testimony of Oleg Chernyavsky, Exec. Dir. of Legis. Affs., NYPD) (describing the criteria for inclusion in the database).

197. Nick Pinto, NYPD Added Nearly 2,500 New People to Its Gang Database in the Last Year, INTERCEPT (June 28，2019), https://theintercept.com/2019/06/28/nypd-gang-database-additions/ [https://perma.cc/2W4W-6B5F]. 
database and NYPD's "Domain Awareness System." 198 Transparency litigation has also been a critical avenue for academic researchers and advocates to gain access to information about the demographics of those whom the city's Criminal Group Database includes. ${ }^{199}$

Elsewhere in the United States, open records efforts have also supplemented substantive lawsuits seeking reform of gang policing strategies. In 2018, ProPublica-Illinois obtained access to the de-identified data from Chicago's gang database after filing a state open records request. ${ }^{200}$ The Chicago Police Department (CPD) was using a data "warehouse" called the Citizen and Law Enforcement Analysis and Reporting System (CLEAR) to track gang affiliations based on certain types of inputs, including social media posts, tattoos, and arrest records. ${ }^{201}$ CLEAR, which was developed through a partnership with Oracle, is part of a broader effort by Chicago police to predict future episodes of violence. ${ }^{202}$ By 2018, when ProPublica published the dataset, CLEAR housed information about over 128,000 individuals. ${ }^{203}$ As ProPublica noted, however, the accuracy of some of the entries was questionable: the database included entries for over a hundred people who were over the age of seventy and several who were over one hundred. ${ }^{204}$ Chicago's Inspector General also audited the gang database and likewise concluded that it was riddled with errors. ${ }^{205}$

198. Verified Petition $\llbracket 18$, NAACP v. NYPD, No. 157383/2018 (N.Y. Sup. Ct. Aug. 8, 2018), NYSCEF No. 1. That case settled after NYPD complied with the request. See Stipulation of Settlement and Discontinuance, NAACP v. NYPD, No. 157383/2018 (N.Y. Sup. Ct. Nov. 18, 2019), NYSCEF No. 34.

199. See Howell, supra note 188, at 15 \& n.91 (documenting how she had to file an Article 78 proceeding in order to compel disclosure of statistical information regarding the gang database under FOIL).

200. Mick Dumke, Chicago's Gang Database Is Full of Errors-and Records We Have Prove It, ProPublicA (Apr. 19, 2018), https://www.propublica.org/article/politic-il-insider-chicago-gangdatabase [https://perma.cc/S48Y-MZY7].

201. Id.; POlicing IN ChI. RSCH. GRP., TRACKed and TARgeted: EARly Findings ON ChICAGO's GANG DATABASE, (Janaé Bonsu \& Andy Clarno eds., 2018), http://erasethedatabase.com/wp-content/uploads/2018/02/Tracked-Targeted-0217.pdf

[https://perma.cc/HH32-GCGX]; see also CitY OF CHI. OfF. OF INSPECTOR GEN., REVIEW OF THE CHICAGO POLICE DePARTMENT'S “GANG DATABASE" 16-17 (2019), https://igchicago.org/wpcontent/uploads/2019/04/OIG-CPD-Gang-Database-Review.pdf [https://perma.cc/7KM8-UHHQ] (listing criteria for designation of individuals as gang-involved).

202. Citizen and Law Enforcement Analysis and Reporting (CLEAR), HARVARD KENNEDY SCH. ASH CTR. FOR DEMOCRATIC GOVERNANCE \& INNOVATION, https://www.innovations.harvard.edu/citizen-and-law-enforcement-analysis-and-reporting-clear [https://perma.cc/SM8Z-R9EZ]; see also ANDREW G. FERGUSON, THE RISE OF BIG DATA POLICING 39-40 (2017) (describing how Chicago is a "laboratory" for person-based predictive policing techniques).

203. Dumke, supra note 200.

204. Id.

205. Matt Masterson, Gang Database 'Strains Police-Community Relations' City Watchdog Says, WTTW NEWS (Apr. 11, 2019), https://news.wttw.com/2019/04/11/gang-database-strains-policecommunity-relations-city-watchdog-says [https://perma.cc/ZPE8-8DWP]. 
A few months after ProPublica published its report, the MacArthur Justice Center filed a class action complaint against the City of Chicago and the CPD on behalf of a number of individual and organizational plaintiffs. ${ }^{206}$ The lawsuit challenged the database on procedural due process, equal protection, and Fourth Amendment grounds. MacArthur sought an injunction that would require Chicago to limit the criteria for entry into the database, provide notice and an opportunity to contest a designation as a gang member, and forbid sharing the gang data with third parties. ${ }^{207}$

Advocates are also resorting to grassroots open records strategies as a remedy for procedural due process concerns. Because NYPD does not notify individuals of their inclusion in the database, many of the tens of thousands of New Yorkers designated as gang affiliates may not even be aware. ${ }^{208}$ In 2018 , the Legal Aid Society, along with dozens of other defense and racial justice organizations, launched "FOIL Yourself," a campaign they described as intended "to help impacted people and communities obtain basic transparency and accountability in how [the] Department classifies New Yorkers as gang affiliates." ${ }^{209}$ NYPD has reportedly denied each of the FOIL requests it has received for information that would disclose whether the requesters are in fact in the Criminal Group Database, citing security concerns. ${ }^{210}$ In November 2018, Keith Shenery, one of the individuals who had FOILed his own records, filed an Article 78 petition to challenge the NYPD's decision to withhold them. ${ }^{211}$ In Chicago, a coalition of racial justice movement groups-Mijente, Organized Communities Against Deportation, and Black Youth Project 100 - have also embraced the grassroots FOIA strategy to help individuals learn whether they

206. Class Action Complaint at 1-2, Chicagoans for an End to the Gang Database v. City of Chicago, No. 18-cv-04242 (N.D. Ill. June 19, 2018), ECF No. 1.

207. Id. at 46-52, 56-58.

208. Pinto, supra note 197 (numbering the Criminal Group Database at 18,084 people).

209. Defenders, Community Groups \& Activists Announce "FOIL Yourself" Campaign Against NYPD Gang Database, LEGAL AID SOC'Y (Feb. 19.2 2018), https://www.legalaidnyc.org/news/2018/2/26/defenders-community-groups-activists-announce-foilyourself-campaign-against-nypd-gang-database [https://perma.cc/PG6K-8BGV]; see Are You in the NYPD Gang Database?, LEGAL AID SOC'Y, https://legalaidfoil.backspace.com [https://perma.cc/SJ5FPRQ6]; GO FOIL YOURSELF! Join Countless Others in AALDEF's Campaign to Help You Find Out What's in Your NYPD File, ASIAN AM. LEGAL DEFENSE \& EDUC. Fund (Mar. 27, 2012), $\mathrm{https}$ ://www.aaldef.org/press-release/go-foil-yourself-join-countless-others-in-aaldefs-campaign-tohelp-you-find-out-whats-in-your-nypd-f/ [https://perma.cc/MX8Y-C3DV]

210. John Annese, NYPD Tells 350 People They Don't Have the Right to Know If They're in a Gang Database, Legal Aid Says, N.Y. DAILY NEWS (Apr. 5, 2019), https://www.nydailynews.com/new-york/ny-legal-aid-challenges-nypd-gang-database-freedom-ofinformation-20190405-jolcfy42o5f3zpqv6nc52bb3uq-story.html [https://perma.cc/WNB8-LAAU]; Alice Speri, NYPD Gang Database Can Turn Unsuspecting New Yorkers into Instant Felons, INTERCEPT (Dec. 5, 2018), https://theintercept.com/2018/12/05/nypd-gang-database/ [https://perma.cc/7KME-VYJV].

211. Verified Petition, Shenery v. NYPD, No. 160935/2018 (N.Y. Sup. Ct. Nov. 21, 2018), NYSCEF No. 1. 
are in CLEAR. ${ }^{212}$ In the face of secretive gang policing practices, the shadow docket is thus playing a critical role in advancing individual rights as well as public knowledge and political change.

\section{Private Sector Partnerships}

The informational dynamics of modern policing technologies grow even more complex when private sector vendors are involved. ${ }^{213}$ As Catherine Crump has documented, law enforcement agencies often begin new surveillance programs and acquire surveillance tools without disclosing those activities to city council and other oversight agencies, let alone the public. ${ }^{214}$ As a result, surveillance and other new policing programs are often initiated without any kind of public input. ${ }^{215} \mathrm{~A}$ web of nondisclosure agreements, some of which purport to override state open records obligations, often surrounds policing technology supplied by private-sector vendors. ${ }^{216}$

At both the state and federal level, civil society groups, scholars, and journalists are using open records litigation to shed light on predictive policing technology, which exemplifies these concerns. ${ }^{217}$ In December 2016, the Brennan Center for Justice filed an Article 78 proceeding in New York to compel NYPD to release records relating to predictive policing technology. ${ }^{218}$ The Brennan Center noted that NYPD had paid to obtain a software technology called Gotham from Palantir, a secretive tech company known to provide surveillance tools to law enforcement. ${ }^{219}$ Among other items, the Brennan Center sought

212. About, ERASE THE DATABASE, erasethedatabase.com/about [https://perma.cc/3HUEHNJ4].

213. See Hannah Bloch-Wehba, Access to Algorithms, 88 FORDHAM L. REV. 1265, 1283-84 (2020) (highlighting "proprietary algorithmic governance" mechanisms in policing); Robert Brauneis \& Ellen P. Goodman, Algorithmic Transparency for the Smart City, 20 YALE J.L. \& TECH. 103, 125 26 (2018) (underscoring the importance of transparency choices for predictive policing algorithms).

214. Crump, supra note 1, at 1640; see also Stephan, supra note 190, at 1014 (noting scarcity of affirmative legislation authorizing police use of gang databases).

215. See Friedman \& Ponomarenko, supra note 1, at 1886-89 (describing different models for community engagement, including commissions, oversight boards, and notice-and-comment rulemaking).

216. See Joh, supra note 182, at 25 (describing nondisclosure agreements cities entered into with Harris Corporation, the manufacturer of stingray technology, which "impose[d] strict conditions of secrecy on law enforcement agencies").

217. See, e.g., Caroline Haskins, Here Are Hundreds of Pages of Official Documents About Predictive Policing in America, VICE (Feb. 26, 2019), https://www.vice.com/en_us/article/gya8jm/hereare-hundreds-of-pages-of-official-documents-about-predictive-policing-in-america

[https://perma.cc/YX9V-B7RC] (highlighting the findings of investigative journalists regarding law enforcement's use of PredPol); see also Joh, supra note 182, at 24-25 (explaining Harris Corporation's insistence on confidentiality).

218. Verified Petition, Brennan Ctr. for Just. v. NYPD, No. 160541/2016 (N.Y. Sup. Ct. Dec. 15, 2016), NYSCEF No. 1.

219. Id. at 2; see also Rob Copeland \& Maureen Farrell, Peter Thiel's Secretive Data Giant Palantir Finally Raking in Cash, WALL ST. J. (Feb. 7, 2019) https://www.wsj.com/articles/peter-thielssecretive-data-giant-palantir-finally-raking-in-cash-11549540803 [https://perma.cc/GQ34-W5QN] (characterizing Palantir as "secretive"). 
contracting documents, purchase records, marketing materials from vendors, and records pertaining to audits of Gotham and other predictive policing tools. ${ }^{220}$

Shortly after the Brennan Center filed its petition, the New York City Council introduced the Public Oversight of Surveillance Technology (POST) Act, which would require NYPD to conduct an impact assessment of each "surveillance technology" that it uses. ${ }^{221}$ The POST Act is one of a number of legislative proposals that impose accountability and transparency requirements on police technology. ${ }^{222}$ Unlike many of its stronger counterparts, the POST Act does not require ex ante legislative approval of surveillance technology but rather provides oversight through requiring post hoc reports. ${ }^{223}$ NYPD nonetheless objected to even this weak form of oversight, and the bill was stalled for nearly three years. ${ }^{224}$ Finally, in June 2020, the city council passed the POST Act along with a suite of other reforms. ${ }^{225}$

Against this background, the Brennan Center's effort to bring NYPD's predictive policing systems into the open took on more significance. NYPD claimed that it could not provide records about the audits or test results from Palantir because the agency had entered into a nondisclosure agreement with Palantir and the other potential vendors. ${ }^{226}$ Releasing information about the accuracy of NYPD's predictive policing tools, it claimed, would jeopardize vendors' trade secrets. ${ }^{227}$ While the court ultimately rejected the trade secrets claim as unfounded, the developers of proprietary tools such as breathalyzers and forensic analysis software have advanced similar trade secrets claims in other law enforcement contexts that impede transparency and accountability

220. Brennan Ctr. for Justice v. New York City Police Dept., No. 160541/2016, 2017 WL 6610414, at *2-3 (N.Y. Sup. Ct. Dec. 27, 2017).

221. The POST Act defines "surveillance technology" broadly to include "equipment, software, or system capable of, or used or designed for, collecting, retaining, processing, or sharing audio, video, location, thermal, biometric, or similar information, that is operated by or at the direction of the department." N.Y.C. LOCAL LAW NO. 2020/065 (amending ADMIN. CODE tit. 14, ch. 1, §14-188; N.Y.C. Charter $\S 803)$.

222. See ACLU, COMMUNITY CONTROL OVER POLICE SurveILlance, https://www.aclu.org/issues/privacy-technology/surveillance-technologies/community-control-overpolice-surveillance [https://perma.cc/WG4R-HZSW]; BAN FACIAL RECOGNITION, https://www.banfacialrecognition.com/map/ [https://perma.cc/HW64-DY6C] (displaying a nationwide map of CCOPS and other anti-surveillance legislation).

223. Ira S. Rubinstein, Privacy Localism, 93 WASH. L. REV. 1961, 2005 (2018).

224. Id. at 2005-06; see also Albert Fox Cahn, Surveillance and the City: Past Time for the POST Act, GOTHAM GAZETTE (Nov. 12, 2019), https://www.gothamgazette.com/opinion/8909-surveillanceand-the-city-past-time-post-act-nypd [https://perma.cc/TN4Y-T5YJ] (noting that the bill has been pending before the Council for over two-and-a-half-years).

225. Wiggers, supra note 20.

226. See Brennan Ctr. for Justice v. New York City Police Dept., No. 160541/2016, 2017 WL 6610414 , at *9 (N.Y. Sup. Ct. Dec. 27, 2017).

227. Id. at $* 9-10$. 
interests. ${ }^{228}$ In response, legislators have begun to consider restricting the assertion of the trade secrets privilege. ${ }^{229}$

Similar efforts are apace to expose police use of facial recognition and surveillance cameras. Law enforcement has turned to private sector vendors, including Amazon and Microsoft, to provide facial recognition software even in the absence of affirmative legislation, meaningful civil liberties safeguards, or transparency obligations. ${ }^{230}$ Amazon's home surveillance subsidiary, Ring, has also entered into agreements with law enforcement to encourage consumers to adopt Ring products. Ring is reportedly also working toward implementing facial recognition within the hardware. ${ }^{231}$ The turn toward facial recognition has raised particular concerns in light of the mixed evidence about the accuracy of its results and the high potential cost of error. ${ }^{232}$ Facial recognition software misidentifies

228. See State v. Loomis, 881 N.W.2d 749, 761-62 (Wis. 2016) (upholding use of proprietary algorithm at sentencing despite defendant's lack of access to critical information about how the algorithm computes risk); see also Rebecca Wexler, Life, Liberty, and Trade Secrets: Intellectual Property in the Criminal Justice System, 70 STAN. L. REV. 1343, 1372-73 (2018) (questioning whether necessity is the proper legal burden to apply to discovery and subpoena motions in the context of forensic DNA analysis systems); Natalie Ram, Innovating Criminal Justice, 112 Nw. U. L. REV. 659, 671-75 (2018); Bloch-Wehba, supra note 213, at 1283-90 (documenting a variety of proprietary algorithmic methods at different stages of the criminal justice process).

229. Recently proposed legislation would amend the Federal Rules of Evidence to require the disclosure of source code and other relevant information to criminal defendants in order to challenge forensic analysis. Press Release, Mark Takano, U.S. Rep., Rep. Takano Introduces the Justice in Forensic Algorithms Act to Protect Defendants' Due Process Rights in the Criminal Justice System, (Sept. 17, 2019), https://takano.house.gov/newsroom/press-releases/rep-takano-introduces-the-justicein-forensic-algorithms-act-to-protect-defendants-due-process-rights-in-the-criminal-justice-system [https://perma.cc/7YA7-WC4J]. In Idaho, the legislature recently enacted a law that requires any pretrial risk assessment algorithms to be "transparent," and specifies that "No builder or user of a pretrial risk assessment algorithm may assert trade secret or other protections in order to quash discovery in a criminal matter by a party to a criminal case." H.R. 118, 65th Leg., 1st Reg. Sess. (Idaho 2019); see also Kate Crawford \& Jason Schultz, AI Systems as State Actors, 119 COLUM. L. REV. 1941, 1945 n.18 (2019) (collecting other state and local initiatives).

230. Hill, supra note 14.

231. See Sam Biddle, Amazon's Ring Planned Neighborhood "Watch Lists" Built on Facial Recognition, INTERCEPT (Nov. 26, 2019), https://theintercept.com/2019/11/26/amazon-ring-homesecurity-facial-recognition/ [https://perma.cc/JRE4-T4CW]; Lauren Goode \& Louise Matsakis, Amazon Doubles Down on Ring Partnerships with Law Enforcement, WIRED (Jan. 7, 2020), https://www.wired.com/story/ces-2020-amazon-defends-ring-police-partnerships/ [https://perma.cc/MS4Q-3BHA]; John Herrman, Who's Watching Your Porch?, N.Y. TIMES (Jan. 19, 2020), https://www.nytimes.com/2020/01/19/style/ring-video-doorbell-home-security.html [https://perma.cc/EY4P-DGDY]; Haskins, supra note 14; Alfred Ng, Amazon's Helping Police Build a Surveillance Network with Ring Doorbells, CNET (June 5, 2019), https://www.cnet.com/features/amazons-helping-police-build-a-surveillance-network-with-ringdoorbells/ [https://perma.cc/CL3T-YUAB]; Louise Matsakis, Cops Are Offering Ring Doorbell Cameras in Exchange for Info, WIRED (Aug. 2, 2019), https://www.wired.com/story/cops-offeringring-doorbell-cameras-for-information/ [https://perma.cc/5F9M-VJFT].

232. See Madeleine Gregory, Amazon's Facial Recognition Misidentified 1 in 5 California Lawmakers as Criminals, VICE (Aug. 13, 2019), https://www.vice.com/en_us/article/ne8wa8/amazonsfacial-recognition-misidentified-1-in-5-california-lawmakers-as-criminals ${ }^{-} \quad$ https://perma.cc/7Y4DC7GV]; DJ Pangburn, San Diego's Massive, 7-Year Experiment with Facial Recognition Technology 
Black and Asian faces as potential matches more frequently than it does White faces and performs particularly poorly for dark-skinned women. ${ }^{233}$ At least two people have been arrested after facial recognition software wrongly flagged them as matches for criminal suspects. ${ }^{234}$

Leading researchers and advocacy groups concerned with the spread of facial recognition technology, including the American Civil Liberties Union (ACLU), Georgetown's Center on Privacy and Technology, and the Electronic Frontier Foundation, rely on open records requests in support of their research and advocacy. ${ }^{235}$ In 2019, the ACLU filed a FOIA lawsuit seeking records related to the use of biometric surveillance and facial recognition by the FBI and Drug Enforcement Administration (DEA). ${ }^{236}$ STOP Spying recently filed a lawsuit against the Metropolitan Transportation Authority (MTA) after the agency would not disclose whether surveillance cameras installed in the Times Square transit hub had facial recognition capabilities. ${ }^{237}$ As policing technologies hoover up vast amounts of private individual data without oversight, notice, due process, or community input, transparency litigation is providing a partial avenue to expose these practices - and to push back.

\section{Electronic Surveillance}

Digital searches are even less transparent than either the traditional, discrete, "transactional" searches or the more "programmatic" practices that

Appears to Be a Flop, FAST Co. (Jan. 9, 2020), https://www.fastcompany.com/90440198/san-diegosmassive-7-year-experiment-with-facial-recognition-technology-appears-to-be-a-flop [https://perma.cc/XJ4Y-3U2D].

233. Joy Buolamwini \& Timnit Gebru, Gender Shades: Intersectional Accuracy Disparities in Commercial Gender Classification, 81 PROC. MACH. LEARNING RSCH. 77, 84 (2018).

234. Kashmir Hill, Wrongfully Accused by an Algorithm, N.Y. TIMES (June 24, 2020), https://www.nytimes.com/2020/06/24/technology/facial-recognition-arrest.html

[https://perma.cc/N5RM-9PJB]; Elisha Anderson, Controversial Detroit Facial Recognition Got Him Arrested for a Crime He Didn't Commit, DETROIT FreE PRESS (July 10, 2020), https://www.freep.com/story/news/local/michigan/detroit/2020/07/10/facial-recognition-detroitmichael-oliver-robert-williams/5392166002/ [https://perma.cc/Q9EB-2T9R].

235. See, e.g., The Perpetual Line-Up: Unregulated Police Face Recognition in America, GEO. L. CTR. ON PRIV. \& TECH., https://www.law.georgetown.edu/privacy-technologycenter/publications/the-perpetual-line-up/ [https://perma.cc/8EGN-RC8N] (relying on over 100 freedom of information requests to gather information about police use of facial recognition); Matt Cagle \& Nicole Ozer, Amazon Teams Up with Government to Deploy Dangerous New Facial Recognition Technology, ACLU (May 22, 2018), https://www.aclu.org/blog/privacy-technology/surveillancetechnologies/amazon-teams-government-deploy-dangerous-new [https://perma.cc/4TQG-64W8] (describing public records requests to jurisdictions partnering with Amazon to deploy its "Rekognition" facial recognition system); Press Release, Elec. Frontier Found., EFF Sues FBI For Access to FacialRecognition Records (June 26, 2013), https:/www.eff.org/press/releases/eff-sues-fbi-access-facialrecognition-records [https://perma.cc/U3HR-RA2K].

236. See Kade Crockford, The FBI Is Tracking Our Faces in Secret. We 're Suing., ACLU (Oct. 31, 2019), https://www.aclu.org/news/privacy-technology/the-fbi-is-tracking-our-faces-in-secret-weresuing/ [https://perma.cc/H4VR-QUWE].

237. Verified Petition, Surveillance Tech. Oversight Project v. Metro. Transp. Auth., No. 150127/2020 (N.Y. Sup. Ct. Jan. 6, 2020), NYSCEF No. 1. 
emanated from Broken Windows. In the digital context, secret searches are not uncommon. Some searches are secret by virtue of the application of complex statutory schemes that keep them out of view; other searches remain secret for mundane administrative reasons. And, when asked to review sealing orders, gag orders, and other secrecy mechanisms related to digital searches, courts have often avoided resolving hard questions about whether secrecy is justified, despite the implications for search and seizure law itself.

Digital search warrants and surveillance orders are often accompanied by a complex web of nondisclosure requirements, prosecutorial practices, and local court rules that prevent public docketing. ${ }^{238}$ For example, numerous federal district courts have established local rules establishing a presumption of secrecy for digital search warrants and surveillance applications and orders. ${ }^{239}$

Law enforcement may also keep searches secret in less formal ways. For instance, the government may engage in "parallel construction" to keep searches from coming to light through "laundering the information in question by concocting independent sources through field interviews, confidential informants, physical searches and seizures, etc." ${ }^{240}$ As Human Rights Watch (HRW) has put it, parallel construction allows the government to "creat[e] fictions to keep potentially questionable investigative activities out of sight."241 In 2013, Reuters reported that the DEA was collecting and distributing telephone records for investigative purposes without disclosing the practice. Instead, DEA agents used "normal investigative techniques to recreate the information." 242 HRW reports that the practice of parallel construction has a long pedigree: as

238. See Bloch-Wehba, supra note 15, at 162; see also Stephen Wm. Smith, Kudzu in the Courthouse: Judgments Made in the Shade, 3 FED. CTS. L. REV. 177, 214-15 (2009) (arguing that transparency in the courts "is the sine qua non of the common-law tradition"); Smith, supra note 15, at 313 (noting dockets presided over by federal magistrate judges "handles tens of thousands of secret cases every year," most of them being "warrant-type applications").

239. See, e.g., D.D.C. LCrR 49(e) (requiring that applications for electronic surveillance be filed under seal, but not requiring a motion to seal).

240. Fairfield \& Luna, supra note 192, at 1042.

241. Hum. RTS. WATCH, DARK SIDE: SECRET ORIGINS OF EVIDENCE IN US CRIMINAL CASES 2 (2018), https://www.hrw.org/sites/default/files/report_pdf/us0118.pdf [https://perma.cc/5VXJ-28GA].

242. John Shiffman \& Kristina Cooke, Exclusive: U.S. Directs Agents to Cover Up Program Used to Investigate Americans, REUTERS (Aug. 5, 2013), https://www.reuters.com/article/us-dea-sodidUSBRE97409R20130805 [https://perma.cc/HJV8-E4QP]. Certain types of foreign intelligence surveillance are often kept secret as well. For example, Section 702 of the FISA Amendments Act authorizes the government to target and collect the communications of non-United States persons outside the United States for foreign intelligence purposes. 50 U.S.C. $\$ 1881$. Many of these programs only came to light because NSA contractor Edward Snowden exposed them. See, e.g., Barton Gellman, Julie Tate \& Ashkan Soltani, In NSA-Intercepted Data, Those Not Targeted Far Outnumber the Foreigners Who Are, WASH. POST (July 5, 2014), https://www.washingtonpost.com/world/nationalsecurity/in-nsa-intercepted-data-those-not-targeted-far-outnumber-the-foreigners-whoare/2014/07/05/8139adf8-045a-11e4-8572-4b1b969b6322 story.html [https://perma.cc/CM2P7KDP]. The secrecy issues related to national security surveillance can, and have, filled volumes. See, e.g., supra notes 40-41; Irina D. Manta \& Cassandra Burke Robertson, Secret Jurisdiction, 65 EMORY L.J. 1313 (2016). 
early as 1976, intelligence agencies considered how they could avoid disclosing classified intelligence to criminal defendants in court cases. ${ }^{243}$

The central role of communications service providers in disclosing user data upon government request also impedes transparency by allowing law enforcement to avoid notifying users about searches of communications records. Most warrants and court orders to compel the disclosure of user information are directed at communications intermediaries. ${ }^{244}$ Under Section 2703 of the Stored Communications Act (SCA), law enforcement can seek a search warrant directed at the communications service provider to obtain the contents of a user's online communications, such as their emails. ${ }^{245}$ Unlike the ordinary search warrant framework, however, the SCA does not require law enforcement to notify the target of an SCA search warrant. ${ }^{246}$ In other words, it is up to the service provider to decide whether to notify its customers that law enforcement has searched their emails. ${ }^{247}$ Indeed, numerous lower courts have agreed that providing notice to the service provider satisfies the government's notice obligations under the SCA. ${ }^{248}$

But the service providers who receive search warrants for their customers' information often are forbidden to notify the targets of searches. Section 2705(b) of the SCA permits the government to seek a court order commanding the service provider not to notify the target of a search. ${ }^{249}$

The result puts communications intermediaries in a distinctively powerful position to either facilitate or impede public knowledge about surveillance. ${ }^{250}$ Tech companies have sometimes mounted successful public campaigns to address surveillance secrecy. In 2016, Microsoft filed a complaint in federal district court alleging that over a period of eighteen months, it had received almost 2,600 secrecy orders preventing it from notifying its customers that the

243. HUM. RTS. WATCH, supra note 241, at 15.

244. See generally Alan Z. Rozenshtein, Surveillance Intermediaries, 70 STAN. L. REV. 99 (2018) (discussing the role of companies like Apple, Google, and Facebook in government surveillance).

245. 18 U.S.C. $\S 2703$.

246. Id. $\S 2703(\mathrm{~b})(1)(\mathrm{A})$.

247. See, e.g., EXEC. OfF. FOR U. S. AtT'ys, SeArChing AND SEIZING COMPUTERS AND OBTAINING ELECTRONIC EVIDENCE IN CRIMINAL INVESTIGATIONS 135 (2009), https://www.justice.gov/sites/default/files/criminal-ccips/legacy/2015/01/14/ssmanual2009.pdf [https://perma.cc/JC9Z-KTF5].

248. See, e.g., In re Application of the U. S. for a Search Warrant for Contents of Elec. Mail, 665 F. Supp. 2d 1210, 1221-22 (D. Or. 2009) (concluding that, "when the property to be seized is in the possession of a third party," the Stored Communications Act and Fourth Amendment require only notice to the third party); Application for Warrant for Email Acct. [redacted]@gmail.com, No. 10-291-M-01 (D.D.C. Nov. 1, 2010) (order granting warrant), https://www.dcd.uscourts.gov/sites/dcd/files/mag10291.pdf [https://perma.cc/8HMM-W3DP].

249. See 18 U.S.C. $§ 2705$ (b) (setting out requirements for separate nondisclosure order).

250. See Rozenshtein, supra note 244; Jonathan Manes, Online Service Providers and Surveillance Law Transparency, 125 YALE L.J.F. 343, 345 (2016) (noting that, given the informational dynamics of compelled disclosure, tech companies are uniquely able to articulate "how the government has construed its surveillance authority"). 
government had searched their records. ${ }^{251}$ Microsoft argued that the secret searches of its users' emails violated their Fourth Amendment rights by evading the constitutionally required notice to the target of a search. ${ }^{252}$ But the court ruled that Microsoft lacked standing to advance a Fourth Amendment claim on behalf of its users. ${ }^{253}$ As a result, the court could not consider the company's argument that the secrecy of digital searches made them unreasonable. ${ }^{254}$ At the same time, Microsoft successfully argued that expansive gag orders infringe their First Amendment rights. ${ }^{255}$ Although Microsoft heralded this victory against secrecy requirements, critics have cast doubt on firms' motivations for challenging secrecy orders and surveillance practices, noting that in the majority of cases, platforms appear to acquiesce to law enforcement demands. ${ }^{256}$

The broader ecology of secrecy has also prompted others to deploy transparency law to unveil digital surveillance practices. A Seattle-based news organization, The Stranger, filed a petition to unseal a secret digital surveillance docket, arguing that the systemic opacity violated the public's First Amendment right of access to government proceedings. ${ }^{257}$ The Stranger explicitly linked the interest in transparency to the fact that the government can often use digital surveillance without probable cause, contending that the lower evidentiary threshold made the public interest more pronounced. ${ }^{258}$ While the Federal Prosecutor's Office opposed the petition, it acknowledged the court's power to adopt changes to its docketing practices and expressed support for a coordinated process to assess the impact of new unsealing procedures. ${ }^{259}$ After mediation, the Federal Prosecutor's Office and the Court Clerk developed new procedures that would make the docket far more transparent, and The Stranger agreed to

251. Complaint 9 5, Microsoft Corp. v. U. S. Dep’t of Just., 233 F. Supp. 3 d 887 (W.D. Wash. 2017) (No. 2:16-cv-00538), ECF No. 1.

252. Id. 9 ฯ 31-37.

253. Microsoft Corp., 233 F. Supp. 3d at 915.

254. Id. at 916 (acknowledging that "some of Microsoft's customers will be practically unable to vindicate their own Fourth Amendment rights" because electronic searches proceed behind a "veil of secrecy").

255. Microsoft's First Amendment claims survived the motion to dismiss. See id. at 911-12. Microsoft ultimately settled with the Department of Justice after it adopted a new administrative policy requiring each secrecy order to have "an appropriate factual basis" and presuming that, "[b]arring exceptional circumstances," a secrecy order should last no longer than one year. Memorandum from Rod J. Rosenstein, Deputy Att'y Gen., U.S. Dep't of Justice to Heads of Dep't L. Enf't Components, Dep't Litig. Components, Dir., Exec. Off. U.S. Att'ys \& All U.S. Att'ys (Oct. 19, 2017), https://www.justice.gov/criminal-ccips/page/file/1005791/download [https://perma.cc/4VLZ-CXSE]. See generally Aviv S. Halpern, Note, Secret Searches: The SCA's Standing Conundrum, 117 MICH. L. REV. 1697 (2019) (arguing the SCA and nondisclosure orders create procedural due violations and Fourth Amendment violations).

256. COHEN, supra note 15 , at 133 .

257. Petition at 1, In re Petition of Index Newspapers LLC to Unseal Elec. Surveillance Dockets, 2:17-mc-00145 (W.D. Wash. Nov. 15, 2017), ECF No. 1.

258. Id. at 23 .

259. Response to Petition at 5, In re Pet. of Index Newspapers LLC, 2:17-mc-00145 (Mar. 13, 2018), ECF No. 14. 
dismiss the case. ${ }^{260}$ Journalists and advocates have employed similar approaches in California, Washington, D.C., and elsewhere to seek access to information about digital surveillance practices. ${ }^{261}$

IV.

\section{POLICING, SECRECY, AND DEMOCRACY}

This Section explains both the positive aspects and potential drawbacks of relying on transparency's "shadow docket" to advance law enforcement accountability. Even if not explicitly, the literature on procedural justice, democratic policing, and community policing rests on a set of assumptions about the value of transparency in promoting public trust, accountability, and compliance with the law. Whether transparency litigation is an effective way of achieving those interests remains to be seen, however.

\section{A. Broadening the Range of Potential Litigants}

Many of the cases outlined in the previous Section produced important records and documents about policing that have generated substantive change, stimulated oversight efforts, prompted public discussion, and motivated additional advocacy. When courts ordered the NYPD to disclose records about SQF and the Trespass Affidavit Program in New York City, the information therein formed the basis of successful class action lawsuits. ${ }^{262}$ When Microsoft challenged the federal government's widespread use of gag orders to obscure digital searches, it extracted a settlement that restricted the use of secrecy orders. ${ }^{263}$

The law of access to government records and proceedings can further incentivize civil society organizations, movement groups, and individuals to bring lawsuits to expose practices and policies that might otherwise go unchallenged. ${ }^{264}$ FOIA, for example, permits "any person" to file a request for

260. Aaron Mackey, Victory: Federal Court in Seattle Will Begin Disclosing Surveillance Records, ElEC. FrONTIER FOUND. (Jan. 23, 2019), https://www.eff.org/deeplinks/2019/01/victoryfederal-court-seattle-will-begin-disclosing-surveillance-records [https://perma.cc/WV5K-VES4].

261. See In re Granick, 388 F. Supp. 3d 1107, 1118 (N.D. Cal. 2019) (holding that the First Amendment right of access does not extend to materials and dockets related to search warrants, wiretaps, SCA orders, pen registers, and the All Writs Act); In re Leopold to Unseal Certain Elec. Surveillance Applications \& Orders, 964 F.3d 1121 (D.C. Cir. 2020) (No. 18-5276); see also Naomi Gilens, New Justice Department Documents Show Huge Increase in Warrantless Electronic Surveillance, ACLU (Sept. 27, 2012), https://www.aclu.org/blog/national-security/privacy-and-surveillance/new-justicedepartment-documents-show-huge-increase [https://perma.cc/Y66C-L32M] (documenting results of a FOIA lawsuit).

262. See supra text accompanying notes 170-173.

263. See supra text accompanying notes 251-256.

264. These features of transparency litigation can help alleviate burdens on poor and underresourced individuals who are directly affected by the decisions they seek to challenge. See BlochWehba, supra note 213, at 1269. 
government records-and a lawsuit compelling their disclosure. ${ }^{265}$ This statutory structure was intended to promote newsgathering, making it easier for journalists and news organizations to gain access to information critical for informed public participation. ${ }^{266}$ FOIA's fee-shifting provision, which awards attorneys' fees to FOIA requesters who prevail in court, was likewise intended to ensure that the "average citizen can take advantage of the law to the same extent as the giant corporations with large legal staffs." ${ }^{267}$ Several states, though by no means all, have adopted similar fee-shifting provisions in state public records acts. ${ }^{268}$ Similarly, the courts have repeatedly held that any member of the press or public may advance the First Amendment right of access to government proceedings because secrecy impinges upon the First Amendment's "structural role... in securing and fostering our republican system of selfgovernment." 269

At least in theory, the fact that anyone can seek access to government records through FOIA or the First Amendment improves the likelihood that the public will learn about secret police programs and surveillance techniques. This is particularly important because secretive and surreptitious policing techniques evade application of the exclusionary rule and thus leave many substantial questions about the constitutionality of surveillance unanswered. ${ }^{270}$ Because the rules on notice are unclear at best, it seems possible that many individuals are arrested on the basis of evidence that is never disclosed to them. ${ }^{271}$ As Georgetown's Clare Garvie noted in the context of facial recognition, law enforcement typically considers identifications produced by a facial recognition system to be "investigative leads," and they rarely disclose information about the role of facial recognition to defendants. ${ }^{272}$

265. 5 U.S.C. $\S 552(a)(2)(D)$; see also Pozen, Freedom of Information, supra note 21, at 110304 (describing statutory scheme).

266. Margaret B. Kwoka, FOIA, Inc., 65 DUKE L.J. 1361, 1371 (2016).

267. H.R. COMM. ON GOV'T OPERATIONS \& SENATE COMM. ON THE JUDICIARY, 94TH CONG., FREEDOM OF INFORMATION ACT AND AMENDMENTS OF 1974 (P.L. 93-502) 170 (Joint Comm. Print 1975), https://www.loc.gov/rr/frd/Military_Law/pdf/FOIA-1974.pdf [http://perma.cc/X2XW-9B4K].

268. See Heath Hooper \& Charles N. Davis, A Tiger with No Teeth: The Case for Fee Shifting in State Public Records Law, 79 Mo. L. REV. 949, 959-60 (2014).

269. Richmond Newspapers, Inc. v. Virginia, 448 U.S. 555, 587 (1980) (Brennan, J., concurring).

270. See Margaret Hu, Big Data Blacklisting, 67 FLA. L. REV. 1735, 1751 (2015) ("[T] he Fourth Amendment does not generally cover big data systems designed to execute day-to-day bureaucratized surveillance.").

271. See, e.g., RASHIDA RICHARDSON, JASON M. SCHULTZ \& VINCENT M. SOUTHERLAND, AI Now, Litigating AlgORithms 2019 US REPORT: New CHALlENGES to GOVERNMENT USE OF ALGORITHMIC DECISION SYSTEMS 13-15 (2019), https://ainowinstitute.org/litigatingalgorithms-2019us.pdf [https://perma.cc/9W7G-FLSA] (describing the intersection between prosecutors' obligations to disclose material exculpatory evidence under Brady v. Maryland and the emergence of algorithmic systems to generate evidence).

272. Clare Garvie, Geo. L. Ctr. on Priv \& Tech., Garbage In, Garbage Out: Face RECOGNITION ON FLAWED DATA $§ 3$ (2019), https://www.flawedfacedata.com/\#results [https://perma.cc/D78W-UPME]. 
But despite their promise, efforts to shed light on records concerning surveillance and policing can also be frustratingly slow. It has been over two years since ProPublica first gained access to de-identified data from Chicago's gang database. ${ }^{273}$ Since that time, the city's Inspector General has issued a damning report about the database, and Lori Lightfoot included a promise to replace the database with a better and more limited alternative in her successful mayoral campaign. ${ }^{274}$

Even though any individual is theoretically able to bring an open records lawsuit, a relatively small number of civil society organizations with in-house interests and expertise in transparency litigation have remained primarily responsible for advancing the shadow docket. Unsurprisingly, some of these organizations, such as the ACLU and the Electronic Frontier Foundation, share interests in transparency and in the substantive privacy issues implicated by policing. ${ }^{275}$ Increasingly, movement groups such as Mijente, Organized Communities Against Deportation, Stop LAPD Spying Coalition, Communities United for Police Reform, and others are also organizing around law enforcement accountability issues and simultaneously advancing transparency as a chief prong of their strategy. ${ }^{276}$ Yet while organizations like Legal Aid Society and Erase the Database are pioneering grassroots open records initiatives to address secretive policing practices, the reality is that established civil liberties organizations are dominating the shadow docket. The outsized presence of wellfunded civil liberties organizations might therefore cast some doubt on whether open government strategies are truly empowering activists and movement

273. See Dumke, supra note 200.

274. Heather Cherone, Follow-Up Audit of CPD's Gang Database Almost Complete. City Council Has Yet to Examine Original Findings, WTTW NEWs (Aug. 24, 2020), $\mathrm{https}$ ://news.wttw.com/2020/08/24/follow-audit-cpd-s-gang-database-almost-complete-city-councilhas-yet-examine-original [https://perma.cc/5P49-Q2LR]; LORI LIGHTFOOT FOR CHI., A STRATEGY FOR PUBLIC SAFETY IN EVERY NEIGHBORHOOD 10 (2019), https://ightfootforchicago.com/wpcontent/uploads/2019/01/LL-Position-paper_StrategyPublicSafety.pdf [https://perma.cc/MYX3A7F5].

275. See About the ACLU's Project on Speech, Privacy, and Technology, ACLU, https://www.aclu.org/other/about-aclus-project-speech-privacy-and-technology

[https://perma.cc/9X78-9SN8] (articulating dedication to freedom of expression and privacy rights); About EFF, ELEC. FRONTIER FOUND., https://eff.org/about [https://perma.cc/8GBV-9A3R] (articulating dedication to "user privacy, free expression, and innovation").

276. See discussion supra Part III.B.1; see also STOP LAPD SPYING COAL., https://stoplapdspying.org/ [https://perma.cc/8TXX-43AW]; CMTYS. UNITED FOR POLICE REFORM, https://www.changethenypd.org/ [https://perma.cc/VWH2-5G64] (calling for passage of the Safer NY Act to enhance transparency and accountability); MOVEMENT 4 BLACK LIVES, DEMOCRATIC COMMUNITY CONTROL OF LOCAL, STATE, AND FEDERAL LAW ENFORCEMENT AGENCIES, ENSURING That Communities Most Harmed by Destructive Policing Have the Power to HiRe AND Fire Officers, Determine Disciplinary ACtion, Control Budgets and Policies, AND SUBPOENA RELEVANT AGENCY INFORMATION, https://m4bl.org/wpcontent/uploads/2020/05/CommControlofLawEnforcement-OnePager.pdf [https://perma.cc/5LDAYQKK] (identifying need for civilian oversight to eliminate "roadblocks to law enforcement transparency and accountability"). 
organizations or whether they chiefly reflect the priorities of non-profit organizations.

Moreover, critics of the "freedom of information" framework have observed that open government's "entitlement" of access to government records has unintended negative effects. Predictably, the flood of requests leads to significant delays and to de facto denials that only requesters with means and access to representation can afford to challenge. ${ }^{277}$ As a result, news media and civil society organizations represent a relative minority of requesters and FOIA litigants, while commercial requesters clog the system with requests for records that financially benefit them. ${ }^{278}$ Though these drawbacks reflect systemic inequities in the open government framework, they are less apparent in the context of policing, where commercial interests are less prevalent (although, of course, still present).

Relying on FOIA and open government to reveal secretive policing practices might also backfire, undermining transparency interests by prompting law enforcement to be less candid. ${ }^{279}$ Open government obligations might thus undermine, rather than advance, law enforcement transparency. In fact, David Pozen contended that the open government framework serves largely to "legitimate the lion's share of government secrecy while delegitimating and debilitating government itself." 280

These critiques sound a cautionary note about the wholehearted embrace of open government norms. On the one hand, experience suggests that law enforcement imperatives will often inevitably trump even the best-designed transparency mandates. On the other hand, the architecture of open government itself might prove unhelpful, or even counterproductive, in trying to promote good governance values.

These dynamics are perhaps less concerning in the context of law enforcement accountability than elsewhere. The combination of judicial deference to law enforcement, lack of notice to defendants, and absence of legislative or other independent oversight mechanisms in both settings already fosters a lack of candor by police. ${ }^{281}$ Policing also has a tendency to rely on

277. See Kwoka, supra note 266, at 1424 ("The sheer volume of commercial requests at some agencies is by definition taxing the system, and can only be making the barriers to the use of FOIA for democracy-enhancing activities all the higher."); see also Pozen, Freedom of Information, supra note 21 , at $1116-17$

278. See Kwoka, supra note 266, at 1380 (noting that, at the four largest FOIA offices researched, commercial requesters "represent[ed] the overwhelming majority" of all requests).

279. See generally Andrew Keane Woods, The Transparency Tax, 71 VAND. L. REV. 1 (2018) (arguing that excess transparency may act as "a kind of tax on the legal system").

280. Pozen, Freedom of Information, supra note 21, at 1100.

281. The courts tend to be highly deferential to executive branch claims of secrecy in national security cases, even outside the context of formal executive privilege or state secrets privilege claims. See Kitrosser, supra note 32, at 504 (describing "nearly insurmountable deference in the realm of national security, as represented by the national security aspect of the Nixon Court's reasoning"); 
"secret law": though internal rules and policies provide key information about the law itself, they are concealed as a government secret, depriving the public and the legislature of the ability to scrutinize these rules. ${ }^{282}$ Secret law raises particularly potent questions about political checkability because it has proven to be resistant to oversight by the lawmaking branch. ${ }^{283}$

Alternative mechanisms might produce better outcomes for criminal defendants, government agencies, and the public. For example, affirmative disclosure of government records might be preferable to the reactive model embraced by FOIA, and legislative monitoring could fulfill much of FOIA's oversight function without its ideological costs. ${ }^{284}$ Affirmative obligations to disclose records of certain categories on an ongoing, regular basis at time intervals defined by statute could undoubtedly help oversight institutions, the public, and civil society organizations to better understand the contours of policing practice. Yet police agencies maintain virtually uncontested control over all of the information relevant to these priorities and to informed decisionmaking and policy-making. ${ }^{285}$

At the same time, police departments may not regularly disclose information even if they are required to do so. For example, NYPD has resisted disclosing data about SQF and fare evasion arrests even after the New York City Council required the agency to publicize the information. ${ }^{286}$ The political realities highlight the need for any alternative or supplement to the open records system to be carefully designed with meaningful remedies.

\section{B. Visibility, Trust, and Legitimacy}

Public trust in police is a paramount value within criminal justice reform efforts and scholarship. ${ }^{287}$ To the extent that scholars and advocates have considered transparency law as an aspect of criminal justice reform at all, the thinking has often reflected a core assumption that transparency breeds good

Samaha, supra note 42, at 935 ("Judicial perception of institutional need supports secrecy beyond claims of executive privilege.”). Similar dynamics pervade ordinary law enforcement cases. See Lvovsky, supra note 57; Barry Friedman, Why Do Courts Defer to Cops?, 130 HARV. L. REV. F. 323 (2017); Kwoka, supra note 57, at 216-17 (describing express judicial deference to law enforcement interests in FOIA cases).

282. Manes, supra note 42; Hafetz, supra note 42; Rudesill, supra note 42.

283. Manes, supra note 42, at 822-23.

284. See Pozen, Freedom of Information, supra note 21, at 1107-08.

285. See, e.g., Gwynne Hogan, NYPD Won't Release Arrest Info on Turnstile Jumping, MTA Board Member Says, DNAINFO (May 22, 2017), https://www.dnainfo.com/newyork/20170522/financial-district/mta-subway-fair-fares-swipe-it-forward-police-nypd [https://perma.cc/JA33-VUQB]; see also Samuel Walker, Science and Politics in Police Research: Reflections on Their Tangled Relationship, 593 ANNALS AM. ACAD. POL. \& SOC. SCI. 137 (2004).

286. See supra at Part III.A.

287. See Bell, supra note 137, at 2058-59 (describing the frequent conflation of trust and legitimacy). 
governance. ${ }^{288}$ For instance, the 2015 report from the President's Task Force on 21 st Century Policing recommended that police agencies should adopt procedural justice and transparency reforms in service of promoting public trust and legitimacy. ${ }^{289}$ With regard to transparency, the Task Force recommended that law enforcement publish their policies, aggregate data about policing, and communicate with the public. ${ }^{290}$ Police chiefs across the nation likewise emphasize transparency as a key aspect of public trust. ${ }^{291}$

But transparency alone does not inexorably breed trust and legitimacy. ${ }^{292}$ The procedural justice model, for example, stresses how compliance with the law is "powerfully influenced by people's subjective judgments about the fairness of the procedures" that the police abide by when engaging with civilians. ${ }^{293}$ At its core, procedural justice insists upon police ability to convey that they make decisions in "neutral, objective, consistent ways." 294

The concept of visibility plays an underappreciated role in facilitating the goals of procedural justice. For the public to consider law enforcement legitimate, and for police to secure compliance with the law, decision-makers need both to "be fair and to be seen as being fair." 295 In other words, it's not enough for police to abide by rules and procedures that are fair yet opaque. To promote the ultimate goal of legal compliance, procedural justice requires not only empirically fair procedures - a proposition that police could demonstrate by making their procedures public, transparent, and participatory—but also the public perception of fairness. ${ }^{296}$

288. Although the classic statement of this principle - "Sunlight is... the best of disinfectants"- belongs to Justice Brandeis, "hundreds of law review articles" borrow from his articulation. Fenster, supra note 46, at 620 n.7, 626 \& n. 28.

289. President's TASK Force on 21St Century Policing, Final Report OF The PRESIDENT'S TASK FORCE ON 21ST CENTURY POLICING 1 (2015), https://cops.usdoj.gov/pdf/taskforce/taskforce_finalreport.pdf [https://perma.cc/75DX-KUHX].

290. Id. at 13; see also id. at 21 (describing how policies requiring independent prosecutors in police-use-of-force cases "demonstrate the transparency to the public that can lead to mutual trust between community and law enforcement").

291. See POLICE EXEC. RSCH. F., ADVICE FROM POLICE CHIEFS AND COMMUNITY LEADERS ON BUILDING TRUST: "ASK FOR HELP, WORK TOGETHER, AND SHOW RESPECT," (2016), https://www.policeforum.org/assets/policecommunitytrust.pdf [https://perma.cc/3545-TVQX].

292. Cf. Bell, supra note 137, at 2081-82 (noting that many policymakers view procedural justice as "relatively easy for police agencies to implement, relatively inexpensive, and relatively noncontroversial," and that without a concomitant focus on the problem of "estrangement," these reforms are unlikely to succeed).

293. Tom R. Tyler, Procedural Justice, Legitimacy, and the Effective Rule of Law, 30 CRIME \& JUST. 283, 284 (2003). Procedural justice is the subject of an immense literature that considers many decision-making contexts beyond policing. See Nancy A. Welsh, Magistrate Judges, Settlement, and Procedural Justice, 16 NEV. L.J. 983, 1023 (2016) (outlining social science research that demonstrates that perceptions of fair process affect perceptions of fair outcomes, compliance, and legitimacy).

294. Tyler, supra note 293 , at 334.

295. Meares \& Tyler, supra note 59, at 535 ("Many judges devote their attention to being fair, i.e., to correctly applying the law to the facts of each case, but do not think about how they can communicate that they are being fair to the parties in the case or to the public more generally.").

296. Id. at 542 . 
Democratic policing takes a slightly different tack, suggesting that the root of police dysfunction is not its opacity or unfairness as such but rather its distanced relationship with ordinary democratic oversight mechanisms. ${ }^{297}$ According to this diagnosis, "virtually none" of the administrative law mechanisms designed to hold the executive branch in check-including transparency obligations - apply to police. ${ }^{298}$ Advocates of democratic policing and other like-minded reformers propose an analogy between law enforcement agencies and other executive branch agencies. ${ }^{299}$ By emphasizing the role of lawmaking and public participation in legitimating policing, democratic policing scholarship argues for redistributing the authority to oversee police to a broader set of actors and thus for recentering the public as the ultimate source of police power. ${ }^{300}$

Both of these approaches recognize that, without deeper commitments to building trust and more enduring systems for oversight and democratic control, transparency will not legitimate police authority. But an absence of visibility also exacerbates mistrust: opacity is looked on with suspicion. ${ }^{301}$

Although proponents of transparency litigation often argue that exposing policing practices will advance trust, there may be reason to doubt this assumption. ${ }^{302}$ Critics have called transparency "overvalued." ${ }^{303}$ For one thing, the claim that transparency produces social trust or other desirable outcomes has not been the subject of much rigorous empirical examination. ${ }^{304}$ Indeed, one meta-analysis found that transparency's relationship to trust is inconsistent at

297. See Friedman \& Ponomarenko, supra note 1.

298. Id. at 1843.

299. See, e.g., Friedman \& Ponomarenko, supra note 1; Renan, supra note 57; Christopher Slobogin, Policing as Administration, 165 U. PA. L. REV. 91 (2016).

300. See, e.g., Friedman \& Ponomarenko, supra note 1, at 1886-89 (describing different models for community engagement, including commissions, oversight boards, and notice-and-comment rulemaking); $c$. Kitrosser, supra note 1, at 1173-74 (describing how the legislative process is engineered for transparency while the executive branch is designed to facilitate secrecy).

301. Cf. Fenster, supra note 21, at 931 ("When significant segments of the public believe that corruption or conspiracy permeate government, their desire for transparency becomes obsessive and their ability to rationally sort and interpret information suffers as a result."); Malte Ziewitz, Governing Algorithms: Myth, Mess, and Methods, 41 SCI., TeCH., \& HuM. VAlues 3, 6 (2016) ("[O]pacity of operation tends to be read as another sign of influence and power.")

302. See, e.g., Intervenors Memorandum of Law in Support of Motion for Intervention and for Access to Court Documents at 17, People v. Van Dyke, 17-cr-0428601 (Ill. Cir. Ct. Mar. 6, 2018), https://www.rcfp.org/sites/default/files/litigation/Van\%20Dyke_2018-03-

06_intervenors_memorandum_of_law_in_support.pdf [https://perma.cc/Q9DK-5WCW] ("Public scrutiny over the court system promotes community respect for the rule of law, provides a check on the activities of judges and litigants, and fosters more accurate fact finding." (quoting A.P. v. M.E.E., 354 Ill. App. 3d 989, 999 (1st Dist. 2004))); see also supra Part III.C.1 (describing invocation of trust in the context of The Stranger's effort to unseal electronic surveillance records).

303. Amitai Etzioni, Is Transparency the Best Disinfectant?, 18 J. POL. PHIL. 389 (2010); see also Pozen, Ideological Drift, supra note 21, at 100-01 (documenting how open data mandates have come at the expense of government's ability to function); Samaha, supra note 42, at 922 (observing some of the costs of "transparency").

304. Etzioni, supra note 303, at 394-95 (noting the dearth of empirical evidence). 
best and inverse at worst. ${ }^{305}$ For another, several examples suggest that, in order to promote "accountability and responsiveness" in government, transparency must be paired with other avenues of public engagement. ${ }^{306}$

Perhaps the rise of the shadow docket might be interpreted, rather than advancing trust, as giving voice to communities and movements that distrust police. ${ }^{307}$ As Monica Bell has put it, when it comes to police, "many poor African Americans might see police as a legitimate authority in the ideal, and might even empathize with some police officers' plight, but they find the police as a whole too corrupt, unpredictable, or biased to deem them trustworthy." 308 But the transactional frame of Fourth Amendment jurisprudence, which focuses on individuals' rights and the remedy of suppressing the fruits of unlawful searches and seizures, fails to truly reflect what Bell calls "legal estrangement." Instead, as she notes, policing cases "send messages to groups about social inclusion and, indeed, social citizenship."309

Transparency litigation, like other civil litigation strategies, might thus reflect a conscious effort to dismantle, contest, and resist law enforcement institutions rather than to support their trustworthiness or legitimacy. This strain of advocacy, scholarship, and critique - what some have called "radical," "progressive" or "left"-aims not to legitimate police authority but to utterly reconstruct the relationship between police and communities. ${ }^{310}$ The task of empowering the public - in particular, the public most affected by law enforcement and mass incarceration - is central to this project. ${ }^{311}$

And while one might be faulted for believing that transparency alone could give rise to meaningful accountability or reform, the emergence of the shadow docket illustrates a conviction that transparency litigation can spur "both popular and legislative scrutiny." 312 To the extent transparency deflates other efforts to encourage regulation or public participation - even if temporarily - it may be counterproductive. ${ }^{313}$ But in the efforts outlined above, transparency litigationsometimes brought by legislative actors themselves or in tandem with legislative strategies - tends not to exhaust the potential for public engagement but rather to aid it. Indeed, in light of the informational dynamics of modern policing, it is

305. Gregory A. Porumbescu, Using Transparency to Enhance Responsiveness and Trust in Local Government: Can It Work?, 47 STATE \& LOC. GOV'T REV. 205, 210 (2015).

306. Id. at 208.

307. Bell, supra note 137, at 2086-87.

308. Id. at 2087.

309. See id. at $2140-42$ ("Judges who rule on the constitutionality of searches should keep in mind the stakes of giving too much leeway to the police.").

310. See, e.g., id.; Akbar, supra note 22; Simonson, supra note 23.

311. See, e.g., Jocelyn Simonson, Police Reform Through a Power Lens, 130 YALE L.J. 778 (2021).

312. Pozen, Freedom of Information, supra note 21, at 1111.

313. See, e.g., Etzioni, supra note 303, at 390 ("[I]deological advocates of transparency maintain that it can obviate the need for most—if not all—government controls."). 
difficult to imagine an effective regulatory strategy that operates without a degree of information-forcing.

\section{The Transparency Two-Step}

Perhaps the most significant drawback of the shadow docket is that it is a deeply flawed mechanism for actually reining in policing. Transparency litigation, like the law itself, is a tool. ${ }^{314}$ But it is not clear that it's the right tool. ${ }^{315}$

These cases are not about transparency for transparency's sake, and transparency does not provide an adequate substitute for more robust and meaningful accountability obligations. Movements, individuals, and civil society organizations have turned to transparency law not because it is superior at accomplishing police accountability but because, given the constraints of politics and constitutional doctrine, it is the only viable option to get the foot in the courthouse door. ${ }^{316}$ Often, as the foregoing analysis underscores, litigants deploy transparency law to establish a foundation for further reform or accountability. Transparency litigation is thus an initial step on the pathway to substantive reform. If this diagnosis is accurate to any significant degree, it should prompt us not to embrace transparency as a standalone cure for what ails law enforcement, but to recommit to broadening the avenues for police accountability.

Consider the story of police cameras. On October 20, 2014, Chicago police officer Jason Van Dyke shot and killed teenager Laquan McDonald. ${ }^{317}$ Van Dyke and several other law enforcement officers had responded to a call reporting an individual breaking into cars. ${ }^{318}$ According to official accounts, the officers had used their squad cars to box in the seventeen-year-old suspect, who was carrying a knife in one hand. ${ }^{319}$ A police union spokesman told the Chicago Sun-Times, "An officer shot him in the chest when he refused to comply with orders to drop the knife and continued to approach the officers." ${ }^{320}$ Soon afterwards, a whistleblower approached Craig Futterman, a law professor at the University of Chicago, and Jamie Kalven, an independent journalist, and told

314. Seth W. Stoughton, Police Body-Worn Cameras, 96 N.C. L. REV. 1363, 1369 (2018) ("Tools should be used to accomplish normatively desirable tasks when they are an efficient way of accomplishing or facilitating that task. Following that logic, tools should not be used when the task itself is inappropriate or when the tool is ill-suited for the job at hand.").

315. See supra Part IV.A-B (articulating critiques of transparency litigation).

316. For example, the Ligon plaintiffs would not have been satisfied if NYPD had simply disclosed records about Operation Clean Halls, but had not ended the program. See supra text accompanying notes 170-173.

317. Mary Mitchell, Questions Surround a Chicago Police Fatal Shooting of a Teen, CHI. SuNTIMES (June 24, 2016) https://chicago.suntimes.com/2016/6/24/18448853/questions-surround-achicago-police-fatal-shooting-of-a-teen [https://perma.cc/AH82-RUYN].

318. Id.

319. Id.

320. Id. 
them that McDonald had been retreating, not advancing; that a White male officer had shot McDonald as he was backing away; that the officer had "fired repeatedly into his body"; and that the CPD was not investigating the murder. ${ }^{321}$

Public outrage and a "pitched legal battle doggedly pursued by local investigative journalists" ensued. ${ }^{322}$ Kalven filed a FOIA request for the autopsy report, which showed that McDonald had been shot sixteen times. ${ }^{323}$ The next month, Chicago's city council approved a \$5 million settlement to McDonald's family, on the condition that the family not release the footage from the dashboard camera that recorded the murder. ${ }^{324}$ The nondisclosure provision prompted public outrage, and in April, Alderman Howard Brookins called on the $\mathrm{CPD}$ to release the footage from the dashboard camera that recorded the murder. ${ }^{325}$ In May 2015, freelance journalist Brandon Smith filed a FOIA request for the dashcam video. ${ }^{326}$ And in November, only hours after Van Dyke was charged with first-degree murder, the video was released to the public, showing Van Dyke opening fire six seconds after getting out of his squad car as McDonald was walking away. ${ }^{327}$

The story of Laquan McDonald is not a righteous story about the power of government transparency to expose wrongdoing and promote accountability.

321. Craig Futterman \& Jamie Kalven, Laquan McDonald, INVISIBLE INST. (Dec. 8, 2014), http://invisible.institute/news/2014/laquan-mcdonald [https://perma.cc/E64D-MACM]; Curtis Black, How Chicago Tried to Cover up a Police Execution, CHI. REP. (Nov. 24, 2015), https://www.chicagoreporter.com/how-chicago-tried-to-cover-up-a-police-execution/ [https://perma.cc/54FX-QER3].

322. POLICE ACCOUNTABILITY TASK FORCE, RECOMMENDATIONS FOR REFORM: RESTORING Trust Between the Chicago Police and the Communities They Serve 3 (2016), https://chicagopatf.org/wp-content/uploads/2016/04/PATF_Final_Report_4_13_16-1.pdf

[https://perma.cc/Z6TY-ZFS4]; see also Keeanga-Yamahtta Taylor, Five Years Later, Do Black Lives Matter?, JACOBIN MAG. (Sept. 30, 2019), https://jacobinmag.com/2019/09/black-lives-matter-laquanmcdonald-mike-brown-eric-garner [https://perma.cc/3X6U-QV4B] (noting the formative and essential role of Black organizing in producing the Task Force's report at all).

323. Jamie Kalven, Sixteen Shots, SLATE (Feb. 10, 2015), https://slate.com/news-andpolitics/2015/02/laquan-mcdonald-shooting-a-recently-obtained-autopsy-report-on-the-dead-teencomplicates-the-chicago-police-departments-story.html [https://perma.cc/9A9V-WUBL].

324. Mary Mitchell, Why the City Doesn't Want Video of Laquan McDonald's Shooting Released, CHI. SUN-TiMES (June 24, 2016), https://chicago.suntimes.com/2016/6/24/18479492/whythe-city-doesn-t-want-video-of-laquan-medonald-s-shooting-released [https://perma.cc/W9E4XJWD].

325. See, e.g., Fran Spielman, Alderman Demands Release of Video of Police Officer Shooting Black Teenager, CHI. SUN-TiMES (Apr. 14, 2015), https://chicago.suntimes.com/2015/4/14/18377011/alderman-demands-release-of-video-of-policeofficer-shooting-black-teenager [https://perma.cc/GQP4-545U]

326. Jeremy Borden, How a Little-Known, Uber-Driving Freelancer Brought the Lawsuit That Forced Chicago to Release a Police Shooting Video, Colum. Journalism ReV. (Nov. 25, 2015), $\mathrm{https}: / / w w w . c j r . o r g /$ united_states_project/brandon_smith_chicago_police_laquan_mcdonald.php [https://perma.cc/5DFF-84CL].

327. Jason Meisner, Jeremy Gorner \& Steve Schmadeke, Chicago Releases Dash-cam Video of Fatal Shooting After Cop Charged with Murder, CHI. TRIB. (Nov. 24, 2015), https://www.chicagotribune.com/news/breaking/ct-chicago-cop-shooting-video-laquan-mcdonaldcharges-20151124-story.html [https://perma.cc/S5YU-BSUU]. 
Rather, Laquan McDonald's tragic and untimely death exposed how deep pathologies within CPD narrowed the opportunities to hold Van Dyke accountable and thus compelled advocates to turn to transparency law to expose the wrongdoing. In their initial blog post, Kalven and Futterman expressed exhaustion with the endless repetition of a cycle of impunity. "A black man is shot by a Chicago police officer. Police sources at the scene say the shooting was justified. The Independent Police Review Authority says it is investigating the incident. Then silence." ${ }^{\prime 28}$ Only if the truth would come out, they seemed to say, would accountability be possible.

Systemic reform has followed from the McDonald shooting to address both the racist police violence in Chicago and the police culture of secrecy that embraced coverups and other attempts to conceal widespread wrongdoing. The State of Illinois sued the Chicago Police Department for a pattern and practice of using excessive force in Black and Latinx communities in Chicago. ${ }^{329}$ The state pointed out that the CPD exhibited a disproportionately high use of force against African-American and Latinx people, and that its Independent Police Review Authority sustained a disproportionately low percentage of misconduct complaints - only 2 percent. ${ }^{330}$ In 2016, reformer Kim Foxx was elected as the State's Attorney for Cook County. ${ }^{331}$ In 2019, a federal court approved a historic consent decree to reform the Chicago Police Department. ${ }^{332}$

Those reforms undoubtedly flowed from the public outrage over McDonald's murder. But they also illustrate that the correct response to abuses of police authority is not to rely on transparency as a remedy, but rather to use all the tools at our disposal to dismantle and reconstruct law enforcement: litigation, regulation, legislation, law reform, and "non-law" mechanisms included. ${ }^{333}$

V.

\section{TRANSPARENCY REMEDIES}

Investigative methods are not at the fringe of what communities are concerned about with regard to law enforcement: they are the core. SQF, Broken Windows, and their digital counterparts have prompted pushback from civil society and social movements not because they are symptomatic of broader

328. Futterman \& Kalven, supra note 321.

329. Complaint, Illinois v. City of Chicago, No. 17-cv-6260, (N.D. Ill. Aug. 29, 2017).

330. Id. ๆฯ 36-39, 130.

331. Miles Kampf-Lassin, Chicago's Political Revolution, IN THESE TIMES (Feb. 12, 2019), http://inthesetimes.com/features/chicago_mayor_aldermanic_elections_political_revolution_social_m ovements.html [https://perma.cc/55JZ-JPX5].

332. FAQ, CHI. POLICE CONSENT DECREE, http://chicagopoliceconsentdecree.org/faq/ [https://perma.cc/M5T3-K7SR].

333. See Harmon, supra note 16, at 789-90 (describing how much "contemporary legal scholarship on policing does not adequately recognize or foster the project of governing police conduct through law"). 
distrust and estrangement from police; they are the root cause of distrust and estrangement. Against this background, it is all the more important for individuals and organizations to be able to confront these programs, to understand how they work, and to hold them in check. While transparency litigation has become an essential tool for movements, advocacy groups, and journalists alike to address police secrecy, this Section begins to sketch out how other options might be better suited to more directly promote accountability in policing.

\section{A. Transparency Outside the Shadow Docket}

In Section 1983 actions and in consent decrees with police departments, courts have been instituting a variety of transparency-oriented reforms to remedy patterns of unconstitutional police conduct: body cameras, court-appointed monitoring, town hall meetings, and engagement with civil society and community organizations. In so doing, courts are working to make policing more "politically checkable"-both more amenable to oversight and more democratically legitimate.

These initiatives illustrate that transparency remedies need not be restricted to transparency litigation. For instance, the dual strategy employed in the SQF litigation focused on extracting the UF-250 data to demonstrate a pattern of racially biased policing. But the court-ordered remedies also focused on transparency beyond the UF-250. Judge Scheindlin ordered the UF-250 to be revised to include additional fields, including an explanation of the officer's basis for reasonable suspicion and the explanation for why a frisk was performed. ${ }^{334}$ The UF-250 also had to include a "tear-off" portion to be given to "each stopped person at the end of the encounter." 335 Beyond the UF-250, Judge Scheindlin also ordered NYPD to conduct a pilot study of body-worn cameras to determine whether they were effective at deterring unconstitutional SQF encounters. ${ }^{336}$

The district court's approach to transparency went beyond individual documentation, however. Noting that community participation was a "vital part of a sustainable remedy," Judge Scheindlin ordered the parties to participate in a joint remedial process for six to nine months that would center on "input from those who are most affected by the NYPD's use of stop and frisk." "337 The court ordered the Facilitator of the joint remedial process to convene "town hall" meetings in each borough at which the public could participate. ${ }^{338}$ And the output of that joint remedial process also emphasized the need for "greater respect, transparency, and accountability" to facilitate public confidence and

334. See Floyd v. City of New York, 959 F. Supp. 2d 668, 681-83 (S.D.N.Y. 2013)

335. Id. at 682 .

336. See id. at 685.

337. Id. at 686-87.

338. Id. 
trust in the police. ${ }^{339}$ Over NYPD's objections, the district court also ordered the appointment of an independent monitor.

The impact of the Floyd remedies opinion is somewhat uncertain, especially given the "kerfuffle" that ensued when the City appealed and argued that Judge Scheindlin's impartiality had been compromised. ${ }^{340}$ The point, however, is that the remedies opinion lays the groundwork for civil remedies geared toward enhancing public transparency and accountability. The same is true for consent decrees, which some commentators have suggested play an important role in promoting community engagement and democratizing the police. ${ }^{341}$ Recognizing the critical role of law enforcement transparency to political checkability and to the protection of Fourth Amendment rights and values should spur similar initiatives.

\section{B. Procurement Reform}

Constraining law enforcement's opportunities to procure new police technologies is another potentially significant avenue for reform. ${ }^{342}$ Legislatures could use the budgeting process to gain leverage in support of police transparency, requiring police to make certain information available in order to procure new technologies or pay the vendors who supply them. By monitoring and placing conditions on police expenditures, institutions can engage in a form of ex ante oversight that has otherwise been largely fruitless.

An emerging movement for community control of surveillance technology may provide a template for future legislation. In a model bill, the ACLU suggests that jurisdictions adopt reforms that require legislative approval for the acquisition of any new surveillance technology and that law enforcement publish impact assessments and surveillance use policies prior to adopting a new technology. ${ }^{343}$ Similar laws have passed in Nashville, Seattle, Cambridge, and elsewhere. $^{344}$

339. BELEN, supra note 160 , at 11.

340. Emily Chiang, Reviving the Declaratory Judgment: A New Path to Structural Reform, 63 BuFF. L. REV. 549, 604-06 (2015) (explaining the backlash to Judge Scheindlin's opinion); see also Anil Kalhan, Stop and Frisk, Judicial Independence, and the Ironies of Improper Appearances, 27 GEO. J. LEGAL ETHICS 1043 (2014) (critically assessing the dismissal of Judge Scheindlin).

341. See, e.g., Sunita Patel, Toward Democratic Police Reform: A Vision for "Community Engagement” Provisions in DOJ Consent Decrees, 51 WAKE FOREST L. REV. 793 (2016); see also Noah Kupferberg, Transparency: A New Role for Police Consent Decrees, 42 ColuM. J.L. \& SoC. PROBS. 129 (2008).

342. See Crump, supra note 1.

343. Community Control Over Police Surveillance (CCOPS) Model Bill, ACLU, https://www.aclu.org/other/community-control-over-police-surveillance-ccops-model-bill [https://perma.cc/HKB8-JHVY].

344. Mike Maharrey, Nashville Metro Council Passes Ordinance Taking First Step Toward Limiting the Surveillance State, TENTH AMENDMENT CTR. BlOG (June 13, 2017), https://blog.tenthamendmentcenter.com/2017/06/nashville-metro-council-passes-ordinance-takingfirst-step-toward-limiting-the-surveillance-state/ [https://perma.cc/KLF2-MX8E]; Seattle Set to Decide 
Participatory budgeting might promote this principle even more effectively by engaging a community-centered approach to procurement. Initially developed by the Workers Party in Porto Alegre, Brazil, in the late 1980s, participatory budgeting involves unelected citizens in "budgetary decision-making." 345 Generally implemented on a neighborhood or community-wide basis, participatory budgeting calls upon residents to determine how to spend a portion of a city's budget. ${ }^{346}$ In New York City, for instance, a majority of city councilmembers allocate a portion of their districts' budgets to be determined by the community itself. ${ }^{347}$ One premise of participatory budgeting is that it may redirect funds to where the community determines they are most urgently needed. ${ }^{348}$ The Movement for Black Lives, for example, has called for participatory budgeting processes to "integrate human rights" and prioritize the needs of poor Black and Brown communities. ${ }^{349}$

\section{Community Control}

In the absence of Fourth Amendment safeguards, it is all the more critical that alternative institutions might be able to check the police. ${ }^{350}$ Those institutions may include legislative bodies, civilian oversight boards, or community institutions. Redistributing the authority and power to oversee

on the Fate of 29 Different Surveillance Technologies, MYNORTHWEST (Oct. 24, 2018), https://mynorthwest.com/1156263/seattle-surveillance-ordinance-public-comment/ [https://perma.cc/53X2-65GL]; Jenna Fisher, Cambridge Passes Law to Regulate Police Surveillance, PATCH (Dec. 11, 2018), https://patch.com/massachusetts/cambridge/cambridge-passes-law-regulatepolice-surveillance [https://perma.cc/5RDL-S6XN]; Eric Kurhi, Pioneering Spy-Tech Law Adopted by Santa Clara County, MERCURY NEwS (June 7, 2016), https://www.mercurynews.com/2016/06/07/pioneering-spy-tech-law-adopted-by-santa-clara-county/ [https://perma.cc/H9ZN-PL6R].

345. YVES SintOMER, ANJA RÖCKE \& CARSTEN HERZBERG, PARTICIPATORY BUdGETING IN EUROPE: DEMOCRACY AND PUBLIC GOVERNANCE 12 (2016).

346. Isaac Jabola-Carolus, Luke Elliott-Negri, James M. Jasper, Jessica Mahlbacher, Manès Weisskircher \& Anna Zhelnina, Strategic Interaction Sequences: The Institutionalization of Participatory Budgeting in New York City, 19 Soc. Movement StUD. 640, 645 (2020); Jennifer Shkabatur, Cities@Crossroads: Digital Technology and Local Democracy in America, 76 BROOK. L. Rev. 1413, 1465-71 (2011); Colin Crawford, Our Bandit Future? Cities, Shantytowns, and Climate Change Governance, 36 FORDHAM URB. L.J. 211, 244- 46 (2009) (describing participatory budgeting in Brazil as a partial response to a legacy of authoritarian repression).

347. Thad Calabrese, Dan Williams \& Anubhav Gupta, Does Participatory Budgeting Alter Public Spending? Evidence From New York City, 52 ADMIN. \& SOC'Y 1382, 1388-89 (2020) (outlining New York City's participatory budgeting structure).

348. Id.at 1385 ("While more money flowed toward poor neighborhoods, the Brazilian experiment also resulted in public spending reallocated to basic sanitation and health care from other public functions.").

349. Movement 4 Black Lives, Participatory Budgeting at the Local, State, \& FEDERAL LEVEL, https://m4bl.org/wp-content/uploads/2020/05/ParticipatoryBudgeting-OnePager.pdf [https://perma.cc/PNZ4-BHAW]

350. See, e.g., Friedman, UnWarRanted, supra note 95; John Rappaport, Second-Order Regulation of Law Enforcement, 103 CALIF. L. REV. 205 (2015); William Baude \& James Y. Stern, The Positive Law Model of the Fourth Amendment, 129 HARV. L. REV. 1821 (2016). 
policing to a broader set of institutions has the potential to check police misconduct more effectively, as Rachel Harmon observes. ${ }^{351}$

Legislatures in states and cities across the nation have responded to 2020's uprising against police violence by taking action intended to limit police abuses and promote law enforcement transparency. ${ }^{352}$ Yet legislative bodies have had mixed success in exposing police activity, as New York's Police Reporting Law and fare evasion reporting law suggest. ${ }^{353}$ And where legislatures have acted to reconsider, reveal, or put an end to unconstitutional police practices, they have often not been as aggressive as affected communities would like. ${ }^{354}$ By compelling transparency rather than substantive reform, legislatures appear to hew to the fiction that "Transparency is More Powerful than Regulations."

Community advisory bodies might serve two functions at once, by spurring more action by city councils and by enhancing the representation of communities who have historically been excluded from decision-making on policing. ACLU's CCOPS model bill, for instance, calls on cities to appoint a community advisory committee on surveillance that reflects the makeup of the city and that "ensure[s] communities that have historically been disproportionately subjected to government surveillance are well-represented." 356

More "movement-driven" visions have called for community control mechanisms that "truly shift[] power" to affected communities. ${ }^{357}$ The Movement for Black Lives, for instance, calls for direct community control of law enforcement, not simply non-binding, advisory input. ${ }^{358}$ These calls surface important and oft-controversial debates about the institutional design of civilian or community control. ${ }^{359}$ For instance, who ought to appoint the members of a

351. Harmon, supra note 16.

352. Kenny Lo, Assessing the State of Police Reform, CTR. FOR AM. PROGRESS (July 16, 2020), https://www.americanprogress.org/issues/criminal-justice/news/2020/07/16/487721/assessing-statepolice-reform/ [https://perma.cc/9DRD-VGY2] (summarizing selected state and local reforms); Legislative Responses for Policing-State Bill Tracking Database, NAT'L CONF. OF STATE LEGISLATURES (Apr. 12, 2021), https://www.ncsl.org/research/civil-and-criminal-justice/legislativeresponses-for-policing.aspx [https://perma.cc/S6XD-2HAN].

353. See supra Part III.A.

354. See, e.g., Cherone, supra note 274 (discussing how Chicago's city government has failed to take action on the CLEAR database in spite of calls for hearings and an audit that concluded the database was deeply flawed).

355. Etzioni, supra note 303, at 390.

356. Community Control Over Police Surveillance (CCOPS) Model Bill, supra note 343.

357. K. Sabeel Rahman \& Jocelyn Simonson, The Institutional Design of Community Control, 108 CALIF. L. REV. 679, 704 (2020).

358. See MOVEMENT 4 BLACK LiVES, supra note 276.

359. See, e.g., Stephen Clarke, Arrested Oversight: A Comparative Analysis and Case Study of How Civilian Oversight of the Police Should Function and How It Fails, 43 COLUM. J.L. \& Soc. ProBS. 1 (2009); Merrick Bobb, Civilian Oversight of the Police in the United States, 22 ST. LOUIS U. PUB. L. REV. 151 (2003); Nathan Witkin, The Police-Community Partnership: Civilian Oversight as an Evaluation Tool for Community Policing, 18 SCHOLAR 181 (2016); Daniel L. Stageman, Nicole M. Napolitano \& Brian Buchner, New Approaches to Data-Driven Civilian Oversight of Law Enforcement, 29 CRIM. JUST. POL'Y REV. 111 (2018). 
civilian review board, should its recommendations be binding, and ought it have subpoena authority to investigate allegations of misconduct? ${ }^{360}$ Importantly, battles over civilian control also show that the composition of oversight institutions matters to police acceptance of and compliance with those mandates. In other words, police may be so hostile to community-led efforts to control their behavior that community oversight institutions are even less effective than legislative bodies. On the other hand, community-led oversight might be more aggressive than "technocrats" in both seeking access to the information necessary to understand - and put a stop to-policing strategies that perpetuate racial inequity. ${ }^{361}$

Some have expressed doubts about whether community control is truly the best remedy for law enforcement. ${ }^{362}$ Indeed, even within the movement to "democratize" law enforcement, there is substantial disagreement about the proper scope and extent of lay community involvement as opposed to expert-led policy-making. ${ }^{363}$ Resolving these debates is far beyond the scope of this Article. For now, suffice it to say that the particular design choices made in crafting community and civilian control mechanisms affect the extent to which those mechanisms can promote the flow of information to the public.

\section{New Expert Oversight Institutions}

As law enforcement adopts predictive policing and other programmatic surveillance methods, the lessons of government secrecy scholarship are increasingly relevant, perhaps surprisingly so. In a literal sense, cooperation among state, local, and federal law enforcement agencies blurs the distinctions between different law enforcement actors, particularly in contexts such as immigration and national security. ${ }^{364}$ The increasing integration of federal, state

360. Udi Ofer, Getting It Right: Building Effective Civilian Review Boards to Oversee Police, 46 SETON HALL L. REV. 1033, 1035 (2016) ("[T] hese institutions, which range tremendously in scope and power, have often times failed to adequately oversee local law enforcement ... many of these regimes were rigged to fail in the first place ...."); Rahman \& Simonson, supra note 357, at 704-06.

361. See Rahman \& Simonson, supra note 357, at 704; Stops, Transparency, Oversight and Protection Act (STOP Act), supra note 29.

362. See John Rappaport, Some Doubts About “Democratizing” Criminal Justice, 87 U. CHI. L. REV. 711 (2020).

363. See Joshua Kleinfeld, Manifesto of Democratic Criminal Justice, 111 Nw. U. L. REV. 1367, 1376 (2017).

364. See, e.g., Matthew C. Waxman, National Security Federalism in the Age of Terror, 64 STAN. L. REV. 289 (2012); see also David A. Harris, The War on Terror, Local Police, and Immigration Enforcement: A Curious Tale of Police Power in Post-9/11 America, 38 RUTGERS L.J. 1 (2006); Adam B. Cox \& Thomas J. Miles, Policing Immigration, 80 U. CHI. L. REV. 87 (2013); Michael J. Wishnie, State and Local Police Enforcement of Immigration Laws, 6 U. PA. J. CONST. L. 1084 (2004); Abigail Hauslohner, ICE Provides Local Police a Way to Work Around 'Sanctuary' Policies, Act as Immigration Officers, WASH. POST (May 6, 2019), https://www.washingtonpost.com/immigration/ice-provideslocal-police-a-way-to-work-around-sanctuary-policies-act-as-immigrationofficers/2019/05/06/f651ff38-7029-11e9-9eb4-0828f5389013_story.html [https://perma.cc/T5CWFN56]. 
and local law enforcement priorities, and the turn toward data-driven investigative methods, help to explain why local and state oversight institutions have struggled to conduct effective oversight of these activities. As Matthew Waxman has observed, state and local oversight mechanisms for intelligencegathering or other surreptitious investigative methods are largely underdeveloped. ${ }^{365}$ At the state and local level, few institutions have regulatory or oversight capacity comparable to the Privacy and Civil Liberties Oversight Board, federal Inspectors General, the Office of the Director of National Intelligence Civil Liberties Protection Office, or the alphabet soup of other agencies and offices with some authority to oversee intelligence. ${ }^{366}$ Even where local police have dedicated oversight institutions, such as Inspectors General, those institutions may have narrow authority or fractious relationships with police unions. ${ }^{367}$

In light of the informational dynamics of modern policing, it is all the more critical that expert institutions should be empowered to conduct ongoing audits and monitoring of police surveillance. Some jurisdictions have already successfully explored these methodologies: recently, a state agency in California issued a scathing audit report of that state's gang database, CalGang, and a similar report in Chicago has spurred a far-reaching conversation about the future of that city's gang database. ${ }^{368}$

Ex post monitoring and auditing is especially important in the context of Big Data policing because of concerns about data quality, accuracy, and privacy issues. ${ }^{369}$ Even though auditing may not be able to identify every reason why an algorithm reaches an impermissible decision-whether it is biased, discriminatory, or just plain wrong - it remains an important strategy to examine the "actual impact" of algorithms in the real world. ${ }^{370}$

365. Waxman, supra note 364, at 336-37.

366. Margo Schlanger, Intelligence Legalism and the National Security Agency's Civil Liberties Gap, 6 HARV. NAT'L SEC. J. 112, 134-35 (2015) (listing offices with authority to oversee NSA signals intelligence activities).

367. For example, Los Angeles Police Department's (LAPD) inspector general has authority only to oversee the disciplinary process. Office of the Inspector General, LAPD, http://www.lapdonline.org/police_commission/content_basic_view/1076 [https://perma.cc/98LUREA7]. NYPD's inspector general has broader authority, but has clashed with the Police Benevolent Association. Inspector General for the NYPD, N.Y.C. DEP'T OF INVESTIGATION, https://www1.nyc.gov/site/doi/offices/oignypd.page [https://perma.cc/4HFM-VE2W] (general ability to oversee policies, programs, and operations of NYPD); John Surico, Can the New Inspector General Really Change the NYPD?, VICE (Jan. 22, 2015), https://www.vice.com/en_us/article/xd5nza/can-thisguy-really-change-the-nypd-122 [https://perma.cc/G63S-NL6R]; 'Absolutely the Wrong Approach': NYPD Police Union Condemns OIG's Recommendation to Prevent Officer Suicides, NBC NEW YORK (Sept. 26, 2019), https://www.nbcnewyork.com/news/local/nypd-police-union-condemnsrecommendation-to-prevent-officer-suicides/1827897/ [https://perma.cc/Z2CF-ENPR].

368. CAL. STATE AUditor, THE CALGANG CRIMINAL INTELLIGENCE SYSTEM: REPORT 2015130 (2016); CITY OF CHI. OFF. OF INSPECTOR GEN., supra note 201.

369. See Andrew Selbst, Disparate Impact in Big Data Policing, 52 GA. L. REV. 109 (2017).

370. Pauline T. Kim, Auditing Algorithms for Discrimination, 166 U. PA. L. REV. ONLINE 189, 191 (2017). 
The SQF and gang policing examples illustrate that police might not always comply with disclosure or auditing mandates. But perfect adherence is not the goal. Institutionalizing transparency is important because it introduces new ways of checking police conduct and reintroduces methods of oversight in an area that has been outside of the frame. Intangible, privatized, and secretive investigative methods thus raise concerns that accountability problems familiar to the national security context might bleed over into local and state law enforcement as well.

\section{CONCLUSION}

Law enforcement agencies have never had such easy access to technologies of surveillance as they do today. And it has never been so easy for police to operate in secret, without democratic accountability or public input. As the legal options for checking the police dwindle, transparency law has played an outsized role in prompting substantive reform and in mobilizing social change.

But making policing visible is about much more than exposing aggregate data or publishing a list of intrusive police techniques. Visibility is a critical element of democratic oversight by elected officials, legislative bodies, and communities affected by surveillance. The proliferation of new technologies should prompt us to ask not just what rules ought to constrain the police, but what we need to know in order to decide what the rules ought to be. And it should prompt us to reconsider the extent to which the informational dynamics of modern policing, fueled by private-sector vendors and an ever-increasing hunger for more data, intentionally stand in the way of effective oversight. These informational dynamics do not only reflect public policy failures: they reflect a fundamental challenge to the project of police reform and to the democratic legitimacy of policing decisions. 